Effects of High-Flow Experiments from Glen Canyon Dam on Abundance, Growth, and Survival Rates of Early Life Stages of Rainbow Trout in the Lees Ferry Reach of the Colorado River

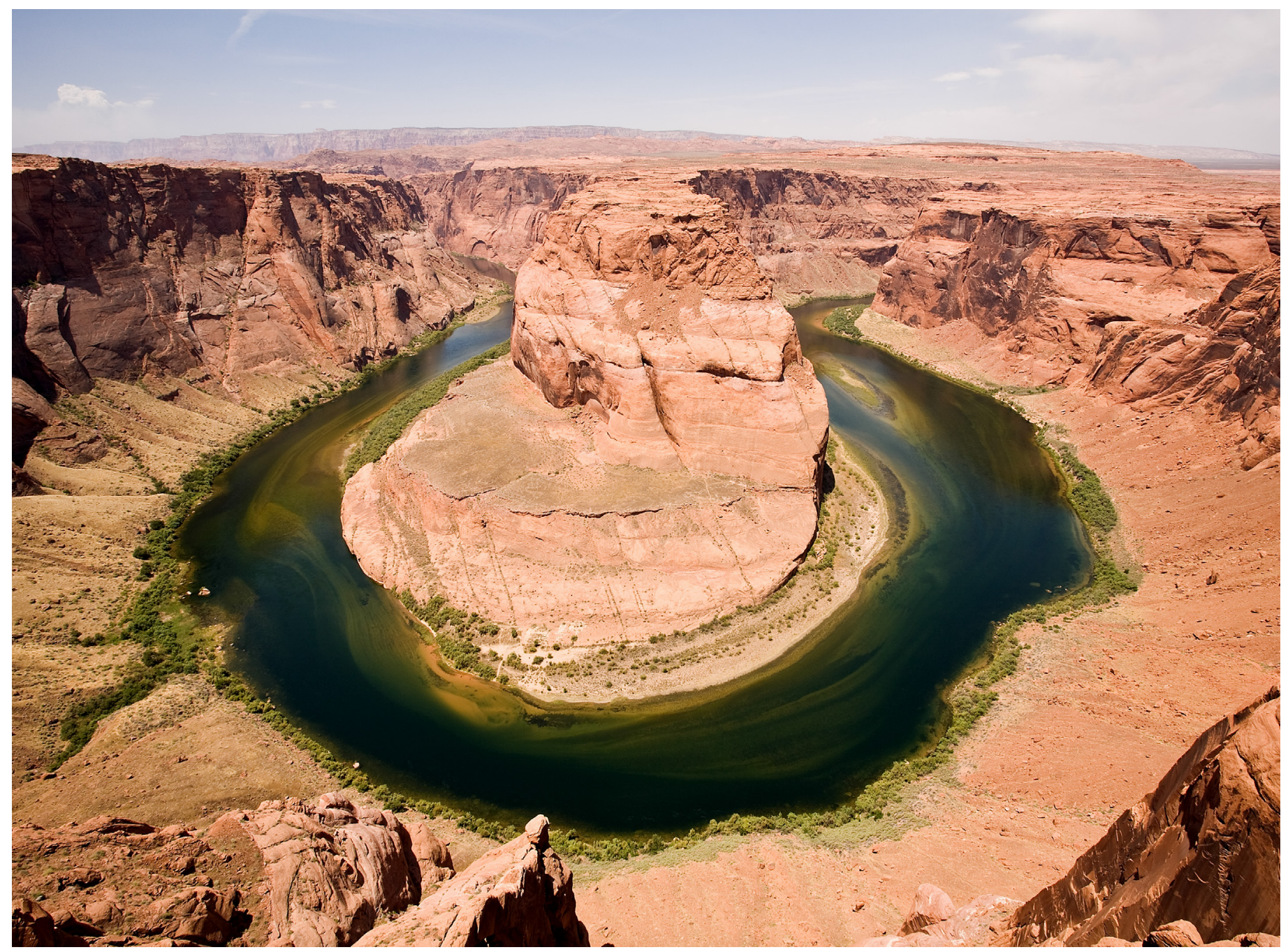

Open-File Report 2010-1034 
Cover: Photograph of Horseshoe Bend, a horseshoe-shaped meander of the Colorado River slightly downstream from the Glen Canyon Dam within Glen Canyon National Recreation Area. (৫ 2006 James Marvin Phelps, Jr., used with permission.) 
Prepared in cooperation with Ecometric Research, Inc., and Northern Arizona University

Effects of High-Flow Experiments from Glen Canyon Dam

on Abundance, Growth, and Survival Rates of Early Life

Stages of Rainbow Trout in the Lees Ferry Reach of the

Colorado River

By Josh Korman, Matthew Kaplinski, and Theodore S. Melis

Open-File Report 2010-1034

U.S. Department of the Interior

U.S. Geological Survey 


\section{U.S. Department of the Interior \\ KEN SALAZAR, Secretary}

\section{U.S. Geological Survey \\ Marcia K. McNutt, Director}

U.S. Geological Survey, Reston, Virginia 2010

For product and ordering information:

World Wide Web: http://www.usgs.gov/pubprod

Telephone: 1-888-ASK-USGS

For more information on the USGS—-the Federal source for science about the Earth,

its natural and living resources, natural hazards, and the environment:

World Wide Web: http://www.usgs.gov

Telephone: 1-888-ASK-USGS

Suggested citation:

Korman, J., Kaplinski, M, and Melis, T.S., 2010, Effects of high-flow experiments from Glen Canyon Dam on abundance, growth, and survival rates of early life stages of rainbow trout in the Lees Ferry reach of the Colorado River: U.S. Geological Survey Open-File Report 2010-1034, 31 p.

Any use of trade, product, or firm names is for descriptive purposes only and does not imply endorsement by the U.S. Government.

Although this report is in the public domain, permission must be secured from the individual copyright owners to reproduce any copyrighted material contained within this report. 


\section{Contents}

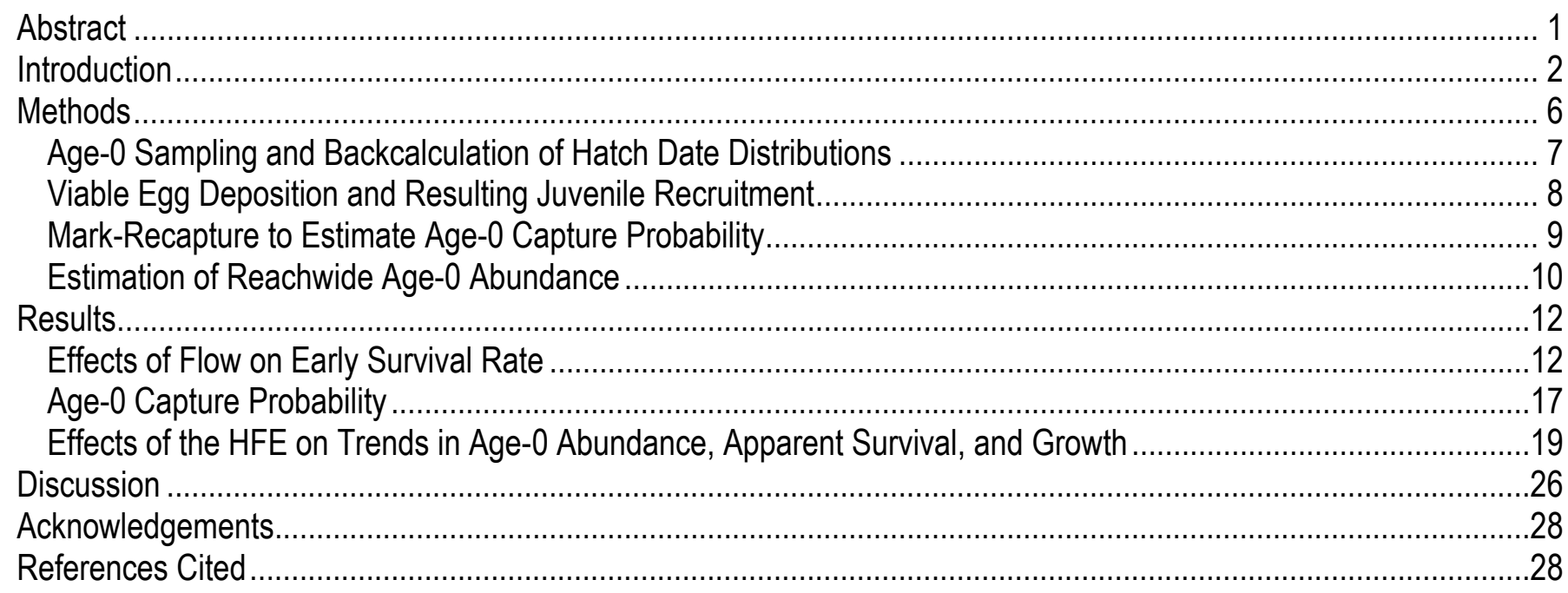

\section{Figures}

1. Map of the study area

2. Hourly discharge from Glen Canyon Dam for calendar years 2003, 2004, 2006, 2007, 2008, and $2009 \ldots 4$

3. The total number of redds counted on each survey and the predicted number that are present from the

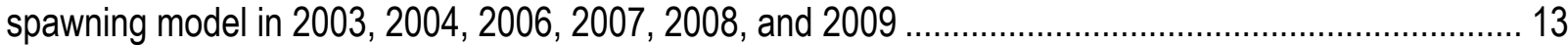

4. Backcalculated and predicted hatch-date distributions in 2003, 2004, 2006, 2007, 2008, and 2009....... 16

5. The relations between the total and viable number of rainbow trout eggs deposited in the Lees Ferry reach and the resulting population size of age-0 trout on July 15, 2003-09 (no data collected in 2005).. 17

6. The relationship between fork length and capture probability for age-0 rainbow trout in the Lees Ferry reach based on boat electrofishing in high-angle shorelines, determined from 43 mark-recapture experiments conducted in summer and fall of 2007 and winter of 2008

7. Trends in the abundance of age-0 rainbow trout in the Lees Ferry reach through the year for several different brood years.

8. Comparison of abundance of age-0 rainbow trout in high-angle habitat in the Lees Ferry reach on trips before and after high-flow experiments were conducted and over similar periods under normal operations

9. Length-at-age relations for age-0 rainbow trout in the Lees Ferry reach based on counts of daily otolith rings in 2003, 2004, 2006, 2007, 2008, and 2009

10. Comparison of annual best-fit length-at-age relations for age-0 rainbow trout in the Lees Ferry reach.. 24

11. Length frequency distributions for age-0 rainbow trout in the Lees Ferry reach in high-angle habitat on trips before and after HFEs were conducted and over similar periods under normal operations.

\section{Tables}

1. Summary of effort and sample sizes used to monitor early life-stage survival and growth of rainbow trout in the Lees Ferry reach, Colorado River ...................................................................................... 7

2. Statistics used to compute early survival rates for rainbow trout in the Lees Ferry reach, 2003-09 ......... 14

3. Statistics from mark-recapture experiments conducted in February and March 2008.............................. 21 


\title{
Effects of High-Flow Experiments from Glen Canyon Dam on Abundance, Growth, and Survival Rates of Early Life Stages of Rainbow Trout in the Lees Ferry Reach of the Colorado River
}

\author{
By Josh Korman ${ }^{1}$, Matthew Kaplinski², and Theodore S. Melis ${ }^{3}$
}

\begin{abstract}
High-flow experiments (HFEs) from Glen Canyon Dam are primarily intended to conserve fine sediment and improve habitat conditions for native fish in the Colorado River as it flows through Grand Canyon National Park, Arizona. These experimental flows also have the potential to affect the rainbow trout (Oncorhynchus mykiss) population in the Lees Ferry tailwater reach immediately below the dam, which supports a highly valued recreational fishery and likely influences the abundance of rainbow trout in Grand Canyon. Understanding how flow regimes affect the survival and growth of juvenile rainbow trout is critical to interpreting trends in adult abundance. This study reports on the effects of HFEs in 2004 and 2008 on early life stages of rainbow trout in the Lees Ferry reach on the basis of monthly sampling of redds (egg nests) and the abundance of the age- 0 trout (fertilization to about 1 to 2 months from emergence) and their growth during a 7-year period between 2003 and 2009.

Multiple lines of evidence indicate that the March 2008 HFE resulted in a large increase in early survival rates of age- 0 trout because of an improvement in habitat conditions. A stock-recruitment analysis demonstrated that age- 0 abundance in July 2008 was more than fourfold higher than expected, given the number of viable eggs that produced these fish. A hatch-date analysis showed that early survival rates were much higher for cohorts that hatched about 1 month after the 2008 HFE (about April $15,2008)$ relative to those fish that hatched before this date. These cohorts, fertilized after the 2008 HFE, would have emerged into a benthic invertebrate community that had recovered, and was possibly enhanced by, the HFE. Interannual differences in growth of age- 0 trout, determined on the basis of otolith microstructure, support this hypothesis. Growth rates in the summer and fall of $2008(0.44$ $\mathrm{mm} /$ day $)$ were virtually the same as in $2006(0.46 \mathrm{~mm} /$ day $)$, the highest recorded during 6 years, even though abundance was eightfold greater in 2008. We speculate that the 60-hour-long 2008 HFE (with peak magnitude about twice that of the annual peak flow during the previous 4 years) increased interstitial spaces in the gravel bed substrate and food availability or quality, leading to higher early survival of recently emerged trout and better growth of these fish through summer and fall. Abundance in 2009 was more than twofold higher than expected, given the estimated number of viable eggs

\footnotetext{
${ }^{1}$ Ecometric Research, Inc., 3560 W. 22nd Avenue. Vancouver, BC, Canada, V6S 1J3

${ }^{2}$ Northern Arizona University, School of Earth Sciences and Environmental Sustainability, Flagstaff, AZ, 86011

${ }^{3}$ U.S. Geological Survey, Southwest Biological Science Center, Grand Canyon Monitoring and Research Center, 2255 N Gemini Dr. (MS 9394), Flagstaff, AZ, 86001
} 
deposited in that year, perhaps indicating that the effect of the 2008 HFE on early life stages was somewhat persistent.

In a 3-week interval that spanned the November 2004 HFE, abundance of age-0 trout that were approximately 7 months old from hatch experienced about a threefold decline, compared to the approximately twofold decrease observed between November and December 2008. Abundance of age-0 trout that were approximately 10 months old from hatch was very similar across sampling trips that spanned the March 2008 HFE. It is uncertain whether the decline in abundance after the November 2004 HFE was the result of higher flow-induced mortality or higher flow-induced downstream dispersal. A focused monitoring effort in Marble Canyon (the reach immediately downstream of the Lees Ferry tailwater) before and after future HFEs is recommended to resolve this uncertainty. Relatively detailed monitoring of early life stages — such as the program described in this study - is essential to establish linkages between Glen Canyon Dam operations, or possibly other factors, and trends in the abundance of important nonnative and native fish populations living downstream within Grand Canyon National Park.

\section{Introduction}

Conservation of fine sediment in Grand Canyon is one environmental goal of the Glen Canyon Dam Adaptive Management Program (GCDAMP). High-flow experiments (HFEs) from Glen Canyon Dam (fig. 1) have been implemented three times since the inception of the program in 1996 (March 1996, November 2004, and March 2008) to determine whether they are effective at conserving the meager remaining sand supplies that continue to enter the Colorado River below the dam throughout Grand Canyon National Park (Wright and others, 2005, 2008). To date, HFEs have increased flows from the dam beyond powerplant capacity to 1,100 to $1,250 \mathrm{~m}^{3} / \mathrm{s}$ for 3 to 7 days (fig. 2). The main objectives of these flows are to rebuild sandbars to increase the area of camping beaches, improve aquatic habitat for endangered native fishes, improve terrestrial habitat for riparian vegetation and associated fauna, and protect archaeological resources (Wright and others, 2005). High flows also have the potential to affect other valued ecological resources downstream of Glen Canyon Dam. One such resource is the population of rainbow trout (Oncorhynchus mykiss) in the Lees Ferry reach, which is a 25-km-long tailwater segment of the Colorado River between the dam and Lees Ferry (fig. 1). This population supports a well-recognized and unique trout fishery, and maintaining this recreational fishery is another one of the 12 goals of the GCDAMP. 


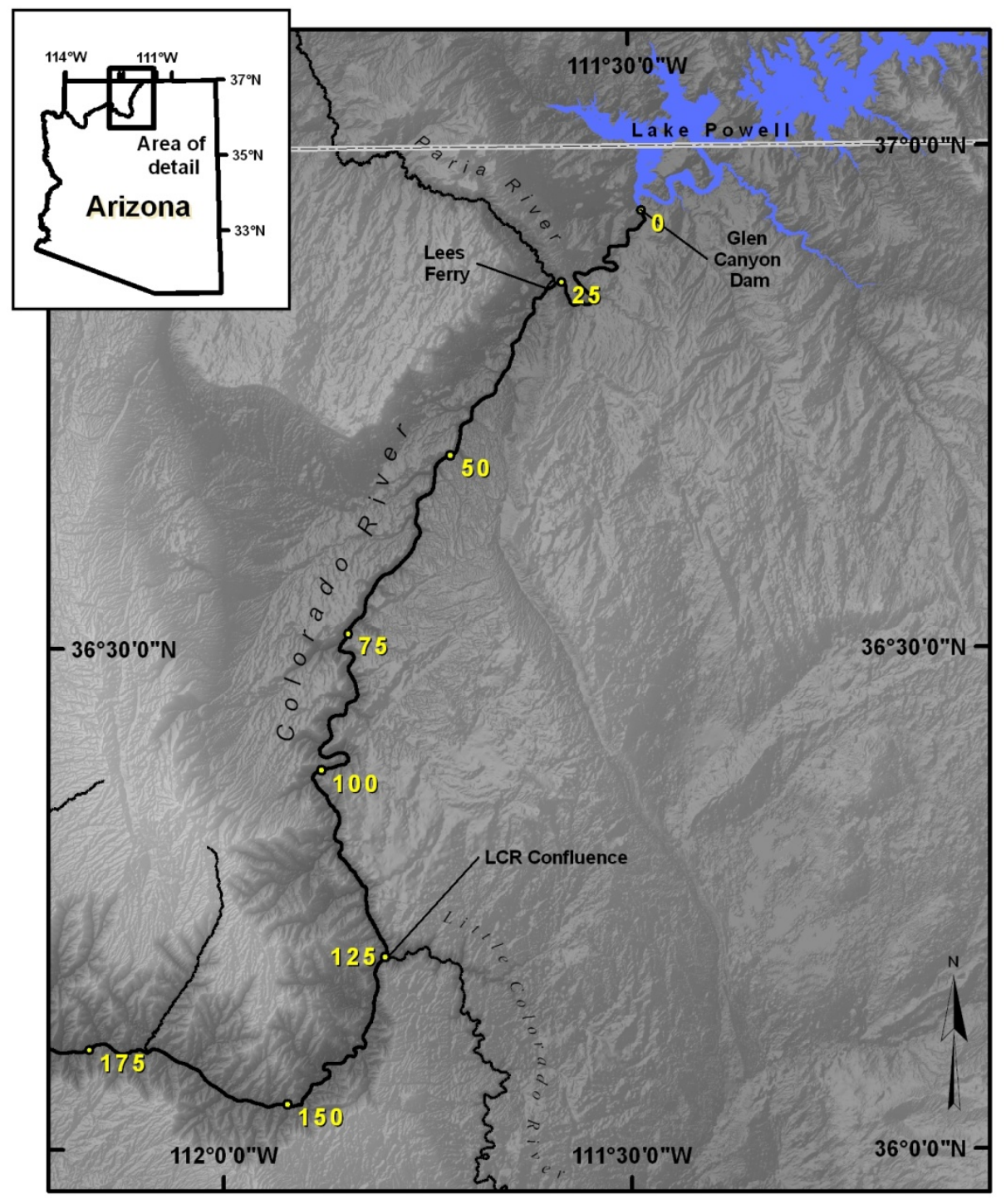

Figure 1. Map of the study area. The Lees Ferry reach is a $25-\mathrm{km}$ tailwater segment of the Colorado River between the Glen Canyon Dam and Lees Ferry. Yellow numbers indicate kilometers downstream from Glen Canyon Dam. 

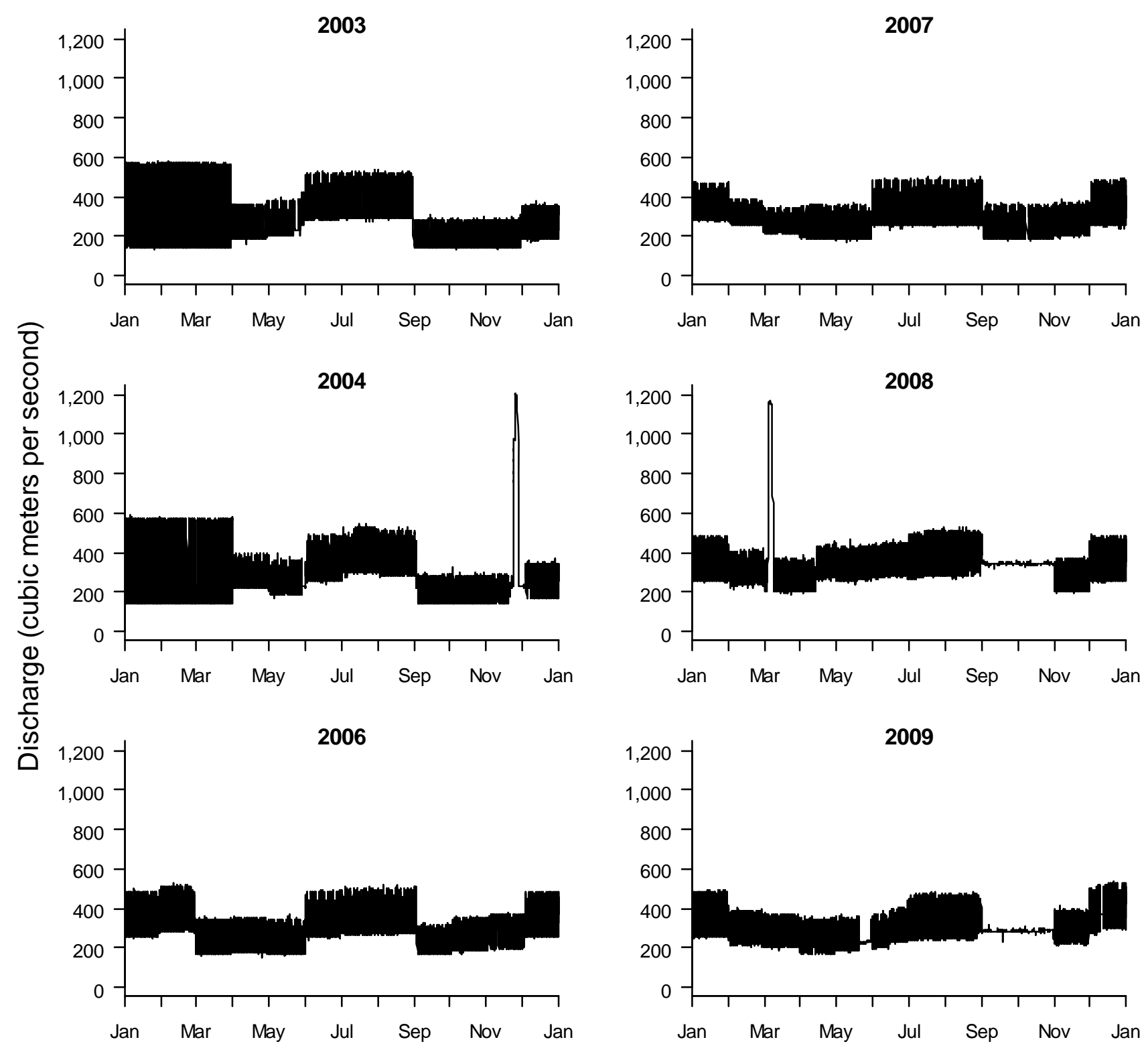

Date

Figure 2. Hourly discharge from Glen Canyon Dam for calendar years 2003, 2004, 2006, 2007, 2008, and 2009. Discharge data for 2005 are not shown because early life-history data were not collected that year.

Experimental, higher than normal winter daily fluctuations from January through March (nonnative suppression flows) were conducted in 2003 through 2005. High-flow experiments were conducted in November 2004 and March 2008. Steady-flow experiments were conducted in fall of 2008 and 2009.

High within-day fluctuations in flow resulting from hydropower load following at Glen Canyon Dam (daily flow range up to $850 \mathrm{~m}^{3} / \mathrm{s}$ ) from the 1960 s to the early 1990 s very likely reduced survival rates of early life stages (eggs, alevins, and age- 0 fish) of rainbow trout in the Lees Ferry reach, limiting natural recruitment rates of juveniles to the adult population (McKinney and others, 2001). In August 
1991, within-day variation in flow was restricted to reduce the erosion rate of fine sediment in Marble and Grand Canyons and to improve navigation and limit stranding of trout in the tailwater reach (U.S. Department of the Interior, 1995). The natural reproductive rate of the rainbow trout population in the Lees Ferry reach was enhanced by the changes in dam operations in the 1990s, and within a decade adult abundance had tripled (McKinney and others, 2001). Rainbow trout abundance in the Colorado River in the vicinity of the river's confluence with the Little Colorado River (LCR), which is $98 \mathrm{~km}$ downstream of the Lees Ferry reach and inhabited by the largest aggregation of humpback chub (Gila cypha) in Grand Canyon, increased more than sixfold between 1995 and 2000, likely in response to reduced flow fluctuations (S. Rogers, Arizona Game and Fish Department, as summarized by Lovich and Melis, 2007). The linkage between populations of rainbow trout in the Lees Ferry reach and in the vicinity of the LCR has been a longstanding uncertainty. Recent analyses support the hypothesis that during the past 10 to 15 years, the Lees Ferry reach has been the primary spawning and rearing site for juvenile trout in the system, and that the abundance of adult trout in the vicinity of the LCR is largely derived from recruitment from the Lees Ferry reach (Coggins, 2008).

Concerns about potential negative effects of high trout abundance on endangered native fish led to the development of an experimental program to reduce trout abundance. A large-scale mechanical removal effort, implemented from 2003 through 2006, focused on reducing the abundance of rainbow trout and other nonnative species in the mainstem Colorado River in the vicinity of the LCR (Coggins, 2008). In addition, operations at Glen Canyon Dam during the winter months (January through March) of 2003 through 2005 were experimentally modified to determine whether such operations would reduce adult trout abundance by reducing survival rates of early life stages. These experimental fluctuating flows, termed "nonnative suppression flows," increased the extent of within-day flow variation from the normal Record of Decision (ROD; U.S. Department of the Interior, 1996) range of 200 to $340 \mathrm{~m}^{3} / \mathrm{s}$ during winter months (under below average inflows from the upper Colorado River Basin) to a range of 140 to $570 \mathrm{~m}^{3} / \mathrm{s}$ (fig. 2). The positive response of the Lees Ferry rainbow trout population to the ROD operating regime (referred to as the modified low fluctuating flow (MLFF)) in the 1990s demonstrated that some aspect of flow stabilization increased natural reproduction. Because the mechanism behind the increase was never established, however, there was considerable uncertainty about whether the nonnative suppression flow regime would be effective at reducing survival rates of early life stages of trout. To address this question, spawning activity, habitat use, growth, and abundance of age-0 rainbow trout in the Lees Ferry reach were monitored from 2003 through 2007 (except 2005) (Korman, 2009). As this project developed, it became apparent that the monitoring approach developed for the experimental flow suppression project could also be used to assess a variety of other experimental flow regimes on early life-history stages, including the non-sandbar-related effects of HFEs. Owing to the fact that this project was ongoing during the November 2004 HFE and because the monitoring had continued through 2007 (a year when new tributary sand inputs below the tailwaters triggered a new round of high-flow research), the project was extended through 2009 , and monitoring and research associated with it were adapted to evaluate the effects of the March $2008 \mathrm{HFE}$ and continued through summer 2009.

Many studies have examined the effects of high flows on survival rates of incubating stages and the growth and survival rates of free-swimming juvenile stages of salmonids. High flows that are sufficient to mobilize fine and course sediments on the streambed during the period when eggs and alevins are incubating in the gravel have the potential to scour or smother redds and reduce survival rates during incubation (Holtby and Healey, 1986; Hartman and Scrivener, 1990; Magee and others, 1996; Montgomery and others, 1999). However, high flows can also flush fine sediments from the interstitial spaces of the stream bottom (Kondolf and others, 1987; Murle and others, 2003), potentially 
increasing survival rates for both incubating and free-swimming life stages that are fertilized after highflow events (Murle and others, 2003). High flows can increase water depth and wetted area and provide access to off-channel habitat, leading to increased survival rates for juvenile fish (Mitro and others, 2003; Lobon-Cervia, 2007). High flows can also displace juvenile fish from preferred habitats and reduce survival (Jensen and Johnsen, 1999; Valdez and others, 2001; Nislow and others, 2002; Einum and Nislow, 2005). Finally, high flows can alter the composition and abundance of the periphyton and invertebrate communities on the stream bottom and in the drift (Benenati and others, 2000; Shannon and others, 2001; Uehlinger and others, 2003), thereby affecting food availability and growth of juvenile fish (Arndt and others, 2002). These studies indicate that HFEs from Glen Canyon Dam certainly have the potential to affect early life stages of rainbow trout in the Lees Ferry reach, but the magnitude and even the direction of response is quite uncertain, given the range of responses observed in other systems.

This study reports on the effects of the 2004 and 2008 HFEs on early life stages of rainbow trout in the Lees Ferry reach (fig. 1). The majority of rainbow trout in this reach spawn between February and April (Korman, 2009). Incubating stages spend approximately 2 months in the gravel before emerging and moving to shoreline areas with very low velocity and shallow depth. Given the timing of spawning and incubation, very few trout would have been incubating during the November $2004 \mathrm{HFE}$, and most age-0 fish would have been 6 to 8 months old from hatch during that experimental release. In contrast, the March 2008 HFE occurred during the peak of spawning and could therefore influence survival rates of incubating life stages and older age-0 trout (about 10 months from hatch) fertilized in the previous year (that is, the 2007 brood). This study focuses on evaluating two main hypotheses concerning the effects of these HFEs on the Lees Ferry trout population. First, this study seeks to evaluate whether the 2008 HFE reduced early survival rates during incubation and shortly after emergence. Because high flows occurred in the middle of the spawning period, the survival rates of cohorts produced from spawning before the 2008 HFE should be lower than those produced after it. A hatch-date analysis (Campana and Jones, 1992) was used to evaluate this prediction. Additionally, if there was a large reduction in early survival rates, the total abundance of age-0 trout in the summer following the 2008 HFE should have been lower than in summers following "control" years when HFEs were not conducted (summers of 2004, 2006, and 2007). This hypothesis was evaluated using a stock-recruitment approach to correct for the effects of interannual variation in egg deposition on age- 0 abundance. Second, this study evaluated whether HFEs reduced survival and growth rates of older age-0 trout ( $>6$ months old from hatch) in 2004 and 2008. Changes in reachwide estimates of age-0 abundance before (November or February) and after (December or March) the HFEs were compared with changes over similar intervals under normal MLFF dam operations. Growth rates of age-0 trout during the summer and fall of 2008, which followed the March HFE, were compared with growth rates in other years.

\section{Methods}

Rainbow trout redds were counted at 27 spawning locations in the Lees Ferry reach (fig. 1) approximately every 2 weeks during the peak spawning period and once per month during nonpeak periods (table 1). A spawn-timing model that incorporated a field-derived estimate of redd survey life of 4 weeks was fit to the redd count data by maximum likelihood to estimate the total number of redds created each year and the timing of spawning. A flow-dependent incubation loss model that integrated the effects of spawn timing, redd hypsometry (proportion of redds by elevation band), and effects of intergravel temperatures on incubation time and mortality was used to predict variation in incubation mortality caused by diurnal flow fluctuations among weekly spawning cohorts. A key assumption of the model is that intergravel temperatures, driven by the frequency and timing of redd dewatering, determine the impact of flow fluctuations on incubation mortality. The model predicts the proportion of 
age-0 fish that are expected to hatch each week and the annual number of viable redds that produced these fish (viable redds). Additional details of field and modeling methods are provided in Korman (2009). This study applied the flow-dependent model to 6 years of data collected from 2003 through 2009, with the exception of 2005, when experimental winter fluctuating flows were released but funding was not available for continued field data collection.

Table 1. Summary of effort and sample sizes used to monitor early life-stage survival and growth of rainbow trout in the Lees Ferry reach, Colorado River.

[Data are summarized by brood year, which is the year in which spawning occurred. In brood years 2007 and 2008, age-0 surveys extended into the following calendar year. No data were collected for brood year 2005. Low-angle shorelines $=$ cobble and vegetated sandbars and debris fans. High-angle shorelines $=$ talus $]$

\begin{tabular}{|c|c|c|c|c|c|c|c|}
\hline & 2003 & 2004 & 2005 & 2006 & 2007 & 2008 & 2009 \\
\hline \multicolumn{8}{|c|}{ Redd Surveys } \\
\hline Number of surveys & 6 & 11 & - & 11 & 7 & 10 & 11 \\
\hline Survey period & Jan-Jun & Nov-Jul & - & Dec-Jun & Dec-Jun & Dec-Jun & Nov-May \\
\hline Total count across surveys & 2,671 & 3,596 & - & 165 & 1,186 & 2,488 & 3,107 \\
\hline Peak count/survey & 723 & 963 & - & 35 & 399 & 571 & 706 \\
\hline \multicolumn{8}{|c|}{ Age-0 Surveys } \\
\hline Number of surveys & $4^{1}$ & 8 & - & 5 & 7 & 11 & 6 \\
\hline Survey period & Jun-Oct & Apr-Dec & - & Jun-Nov & Jun-Mar & May-Mar & May-Nov \\
\hline Total catch across surveys & 586 & 4,451 & - & 1,834 & 5,558 & 14,080 & 12,686 \\
\hline Peak catch/trip & 280 & 1,394 & - & 689 & 1,564 & 3,121 & 3,178 \\
\hline Number of fish aged & 237 & 318 & - & 136 & 152 & 100 & 101 \\
\hline \multicolumn{8}{|c|}{ Age-0 Mark-Recapture } \\
\hline Number of experiments (low angle) & & & - & & 7 & & \\
\hline Number of experiments (high angle) & & & - & & 33 & 10 & \\
\hline Number of marks released & & & - & & 2,960 & 467 & \\
\hline
\end{tabular}

${ }^{1}$ Only low-angle shorelines surveyed in 2003.

\section{Age-0 Sampling and Backcalculation of Hatch Date Distributions}

Annual "observed" hatch-date distributions from 2003 through 2009 were determined by backcalculation and compared to expected distributions predicted from the flow-dependent incubation loss model. Discrepancies between the two resulting distributions provide insight into seasonal patterns in early survival rates (survival between fertilization and 1 to 2 months from emergence). Hatch-date backcalculation requires information on the abundance of age- 0 trout by length category, length-at-age, size-dependent vulnerability to capture, and the postemergent age-0 mortality rate (Campana and Jones, 1992). A detailed description of the sampling design and methodologies used to collect these data and the analytical approach are provided in Korman (2009) but are briefly summarized here. 
Age-0 rainbow trout were captured by backpack electrofishing and boat electrofishing in lowangle shorelines (cobble and vegetated sandbars and debris fans) and high-angle shorelines (talus), respectively. A total of 40 habitat units were randomly selected from a spatially referenced shoreline habitat database for the Lees Ferry reach (Mietz, 2003). Random 30- to 50-m shoreline lengths from these 40 units were sampled monthly using single-pass electrofishing. After each electrofishing pass, fish were anesthetized and fork lengths (length of the fish measured from the tip of the snout to the fork of the tail) were measured to the nearest millimeter $(\mathrm{mm})$. The majority of fish were released back into the site where they were captured. A subsample of three to five fish within 10-mm length categories between 20 and $100 \mathrm{~mm}$ across the 40 sites sampled each trip were sacrificed and preserved in 95percent ethanol to determine daily age from hatch based on examination of otolith microstructure. Monthly sampling trips were generally conducted from May through November from 2003 through 2009 (table 1). On each trip, 2.5 percent and 4.5 percent of the total low- and high-angle shoreline length was sampled, respectively. All sampling was conducted at night at the minimum daily flow to maximize capture probability (Korman and Campana, 2009). Additional trips were conducted in December 2004 and in February and March 2008 to compare abundances before and after the 2004 and 2008 HFEs. Additional sampling trips in December 2008 and February and March 2009 provided data under normal MLFF ROD operations during winter to aid in the interpretation of HFE effects.

Linear models predicting daily age from hatch based on fork length were fit to the otolith data for each year. The age of each fish captured by electrofishing was then determined based on its measured fork length. The hatch date for each fish was calculated by subtracting the estimated age from the date of capture. To account for differences in cumulative mortality between hatch and date of capture among fish of different ages and length-dependent differences in vulnerability to electrofishing, each observation used to determine the backcalculated hatch-date distribution was weighted (that is, divided) by $\mathrm{e}^{\mathrm{M} \cdot \mathrm{Age}} \cdot \mathrm{P}_{\text {Age, }}$, where $M$ is the instantaneous weekly mortality rate and $P$ is the relative vulnerability of each age to sampling, which depends on fish size and habitat type (Korman and others, 2009). Backcalculated hatch-date distributions were computed assuming $M=0.01$, which was determined from a literature review and direct estimates for the Lees Ferry population made on the basis of a stock-synthesis model (Korman, 2009). Backcalculated hatch-date distributions were relatively insensitive to a wide range of $M$ values because age- 0 sampling was conducted over multiple trips and over a period of time that exceeded the duration of the hatching period (Korman, 2009; Campana and Jones, 1992).

\section{Viable Egg Deposition and Resulting Juvenile Recruitment}

Estimates of annual early survival rates to about 1 or 2 months from emergence were based on the ratio of estimated reachwide age- 0 abundance on July 15 to egg deposition. The annual total egg deposition was calculated as the product of the number of viable redds and the number of eggs deposited per redd. We assumed that each female creates a single redd over the spawning season. The mean annual fork length for females was multiplied by a length-standardized fecundity of 58 eggs $/ \mathrm{cm}$ (Allen and Sanger, 1960) to determine the number of eggs per redd. Estimates of early survival rates in 2008, when incubation and emergence success were potentially affected by the HFE, were compared to values from other years.

Early survival rates from salmonids are strongly density dependent (Elliott, 1994; Nislow and others, 2004; Einum and Nislow, 2005). Because of variation in egg deposition across years, as well as variation in flow-dependent incubation losses driven by differences in operations at Glen Canyon Dam, there could be substantial differences in early survival rates because of density-dependent processes alone. This would confound the evaluation of HFE effects. A stock-recruitment approach was therefore 
used to control for these factors: July age-0 abundance from 2003 through 2009 ( $n=6$; no data were collected in 2005) was plotted as a function of the number of viable eggs deposited in the Lees Ferry reach. A Beverton-Holt stock-recruitment model was fit to points collected before the $2008 \mathrm{HFE}$ assuming lognormal error in recruitment (Hilborn and Walters, 1992). Points collected after the March 2008 HFE were compared to this relationship to determine if recruitment was higher or lower than expected following the spring HFE, given the viable egg deposition.

High-angle shorelines were not sampled for age-0 trout in 2003 because the importance of this habitat type was not anticipated at the beginning of this study. A July population estimate for 2003, which was required for the stock-recruitment analysis, was derived by expanding the population estimate in low-angle habitat by the average ratio of abundance in low- $(\mathrm{L})$ to high-angle $(\mathrm{H})$ habitat determined in other years when both habitats were sampled. The July L:H ratio typically ranged from 0.6 to 0.8 , except in 2006, when age- 0 abundance was much lower ( $\left.\mathrm{L}: \mathrm{H}_{2006}=0.4\right)$. Therefore, July $\mathrm{L}: \mathrm{H}$ ratios across all years, excluding $2006(0.71)$, were averaged to expand the estimate of abundance in low-angle habitat to determine total abundance in July 2003.

\section{Mark-Recapture to Estimate Age-0 Capture Probability}

Two-pass mark-recapture experiments were used to estimate capture probability for age-0 trout by habitat type to expand catches obtained by single-pass electrofishing at a larger number of sites and to determine ultimately reachwide abundance. In 2007, age-0 fish were captured for marking by backpack electrofishing in low-angle shorelines at discrete sites ranging from 30 to $60 \mathrm{~m}$ in extent and by boat electrofishing in high-angle shorelines in sites ranging from 50 to $115 \mathrm{~m}$. Fish were batchmarked and were redistributed back into the sites. These same sites were electrofished again 24 hours later, and the number of marks that were recaptured was recorded. Areas upstream and downstream of release sites were also sampled to test the assumption that the populations of marked fish within the sites were effectively closed for the 24-hour period between release and recapture. These data were then pooled across sites and used to develop separate relationships between age-0 fork length (FL) and capture probability (p) for each habitat type (Korman and others, 2009). Seven mark-recapture experiments were conducted between July and August 2007 in low-angle habitat (1,060 marks released), and 33 experiments were conducted in high-angle habitat between July and November 2007 (1,900 marks released; table 1). Additional details regarding field methods and analysis can be found in Korman and others (2009).

The relations of capture probability to fork length were used to expand catches from single-pass index sites to compute reachwide age- 0 abundance. This approach assumes that the relationship estimated in 2007 is stationary and can therefore be applied to data from other years. It also assumes that capture probability estimates from discrete sites are not biased, which requires in part that the populations at these sites are effectively closed (that is, emigration of marked fish between release and recapture events is minimal). These assumptions were well supported by data collected in 2007 (Korman, 2009) but required additional testing if applied to data collected in 2008. Age-0 fish would be significantly larger by late winter 2008 than they were during summer and fall when the 2007 markrecapture experiments were conducted. The capture probabilities for these larger fish may not follow the predictions from the p-FL relationship determined on the basis of data for smaller fish. Larger fish are potentially more prone to emigrate from mark-recapture sites, leading to greater departures from the closure assumption. Additional mark-recapture experiments were conducted during winter 2008 to address these uncertainties.

Six mark-recapture experiments were completed in February 2008, before the HFE, and a total of 265 marks were applied (table 1). Four mark-recapture experiments were completed in March 2008, 
after the HFE, and a total of 202 marks were applied. Because there were few fish using low-angle habitat during winter, experiments were only conducted using boat electrofishing in high-angle habitat. Each mark-recapture experiment was conducted on the basis of sampling $350 \mathrm{~m}$ of shoreline, which was segregated into seven 50-m-long adjacent sections. Fish were initially captured in sections 2 to 6 and given a mark that was unique to each section. Twenty-four hours later, fish were recaptured in sections 1 to 7. This process allowed for an evaluation of the extent of emigration of marked fish from the sections they were initially captured in over the 24-hour period between marking and recapture events. Movements of as much as $300 \mathrm{~m}$ upstream or downstream could be detected using this approach.

We aggregated mark-recapture data in sections 2 to 6 collected in 2008, combined them with data from 2007, and refit the p-FL relationship for high-angle habitat. We fit the original logistic model used in Korman and others (2009):

$$
p L_{j}=\frac{\beta}{1+e^{\frac{-\left(\bar{L}_{j}-\mu_{1}\right)}{\sigma_{1}}}},
$$

where, $p L_{, j}$ is the predicted capture probability for the $10-\mathrm{mm}$ size class $j$ and a mid-point fork length $\bar{L}_{j}$ (in $\mathrm{mm}$ ); $\beta$ is the base capture probability, that is, the capture probability where size is not limiting (that is, when the denominator $=1$ ); and $\mu_{1}$ and $\sigma_{1}$ are the mean and standard deviation of the logistic fork length-vulnerability function that determine the length where capture probability is 50 percent of the maximum and the inverse of the slope of the relationship, respectively. We also fit a two-stage model where capture probability was predicted based on equation 1 if fish were less than or equal to 100 $\mathrm{mm}$, and the following decaying logistic function if fish were greater than $100 \mathrm{~mm}$ :

$$
p L_{j}=\beta\left[1-\frac{1}{1+e^{\frac{-\left(\bar{L}_{j}-\mu_{2}\right)}{\sigma_{2}}}}\right] .
$$

Parameters were established by maximizing the sum of the log likelihood of the binomial probability of the number of recaptures by length class, given the number of total marks and a prediction of capture probability. The single (equation 1) and two-stage (equations $1+2$ ) p-FL models were compared using the Akaike Information Criterion (AIC; Burnham and Anderson, 2002).

\section{Estimation of Reachwide Age-0 Abundance}

Reachwide age- 0 abundance estimates were compared across trips conducted before and after the November 2004 and March 2008 HFEs and over similar periods in years when HFEs were not conducted. Abundance in other months was also computed, and seasonal trends were plotted to provide context to interpret changes in abundance during HFE periods. Estimates of age- 0 abundance in July were used in the stock-recruitment analysis described above. Abundance on each sampling trip was estimated using a two-stage design. Catches from single-pass electrofishing provided an index of population density at 40 shoreline sites sampled each trip. These catch rates were expanded to determine abundance at these sites on the basis of capture probabilities determined from mark-recapture experiments conducted at a smaller number of sites in 2007 and 2008. An estimate of abundance for the reach was then determined by expanding the sum of population abundances across sites by the 
proportion of shoreline habitat that was sampled relative to the total amount in the reach. The approach is similar to the method used by Mitro and Zale (2000) to estimate age-0 trout abundance in the Henrys Fork of the Snake River, Idaho. Mitro and Zale (2000) allowed capture probabilities to vary across trips and used a mean capture probability for all size classes. The approach used here allows capture probability to vary with fish size but assumes that it does not vary across trips. This is reasonable given that variation in the size of age- 0 trout in the Lees Ferry reach is the dominant factor affecting variation in capture probability across survey trips (Korman and others, 2009). Flow was not a significant factor affecting capture probability estimates in 2006 (depletion) or 2007 (mark-recapture). Other factors potentially affecting capture probability, such as sampling technique and water clarity, were constant across trips and years.

The population size at each single-pass electrofishing site sampled in the first stage was determined from

$$
n_{t, h, i}=\sum_{j=1}^{31} \frac{c_{t, h, i, j}}{p_{h, j}},
$$

where $n_{t, h, i}$ is the total population estimate for site $i$ in habitat type $h$ on sampling trip $t ; c_{t, h, i, j}$, is the catch at the site for fish in size category $j$ (20 to $170 \mathrm{~mm}$ in $5 \mathrm{~mm}$ increments); and $p_{h, j}$ is the size-dependent capture probability determined by equation 1 fit to all available mark-recapture data (2007 and 2008) for fish $<140 \mathrm{~mm}$. The total population size in each habitat for the entire Lees Ferry reach was determined from

$$
N_{t, h}=\frac{\sum_{i} n_{t, h, i}}{\frac{\sum_{i} S L_{t, h, i}}{S L_{h}}},
$$

where $N_{t, h}$ is the total population size in habitat type $h$ on sampling trip $t ; S L_{t, h, i}$ is the shoreline length of each sample site (in meters); and $S L_{h}$ is the total length of shorelines of that habitat type in the reach. The denominator in equation 4 represents the total proportion of shoreline of each habitat type that is sampled on trip $t$, which is typically $0.022((20 \mathrm{sites} \times 30 \mathrm{~m} / \mathrm{site}) / 27,800$ (the total length of low-angle shoreline habitat)) and 0.047 (20 sites $\times 50 \mathrm{~m} / \mathrm{site}) / 21,500 \mathrm{~m}$ (total length of high-angle habitat)) in lowand high-angle habitat, respectively. Reachwide age- 0 population estimates between April and November were based on the sum of population estimates in low- and high-angle shorelines. Abundance in low-angle shorelines is very low by November and is negligible during winter months (Korman, 2009). Estimates of abundance in December, February, and March were therefore made on the basis of samples from high-angle shorelines only. To construct length-frequency distributions for a given habitat type and sampling trip, corrected for size-dependent capture probability, $n_{t, h, i, j}$ was computed as an intermediate step in equation 4 , and then summed across sites to determine $n_{t, h, j}$. The proportion of each size class was then calculated as the ratio of $n_{t, h, j}$ to the sum of the population estimates across size classes $\left(N_{t, h}\right)$.

Uncertainty in abundance estimates was determined using a nonparametric bootstrap procedure. For each trial, catch data from single-pass sites within a year, sample period, and habitat strata were randomly selected with replacement. Size-specific catches from the selected sites were expanded to population estimates for each site using equation 3 , which in turn were expanded to a reachwide estimate using equation 4 . The procedure was repeated 200 times for each stratum, and the standard deviation in reachwide population estimates across trials was computed. 


\section{Results}

\section{Effects of Flow on Early Survival Rate}

The date of peak spawning estimated by the spawn-timing model ranged from February 21 (2008) to March 27 (2006) and averaged March 6 across all study years (fig. 3). Estimates of the total number of redds created each year ranged from a minimum of 88 in 2006 to a maximum of 3,264 in 2003 and averaged 1,763 (table 2). Spawning activity was extremely limited in 2006, likely owing to unusually warm temperatures and low dissolved oxygen in water released from Glen Canyon Dam in the fall of 2005. In 2008, the peak count of 571 redds occurred on February 28, just before the HFE, and the total count declined by more than 50 percent to 253 redds on March 14, shortly after the HFE. Redds were very difficult to identify during this survey because very little algae was present, making it hard to distinguish redds from natural depressions in the sediment, especially at sites where redds were located at depths $>1 \mathrm{~m}$. The decline in redd numbers immediately after the 2008 HFE likely reflected a decrease in detection probability rather than a loss of redds owing to scour. The redd count from the first survey after the March HFE therefore was not used to derive the estimate of the total number of redds deposited in 2008 . 

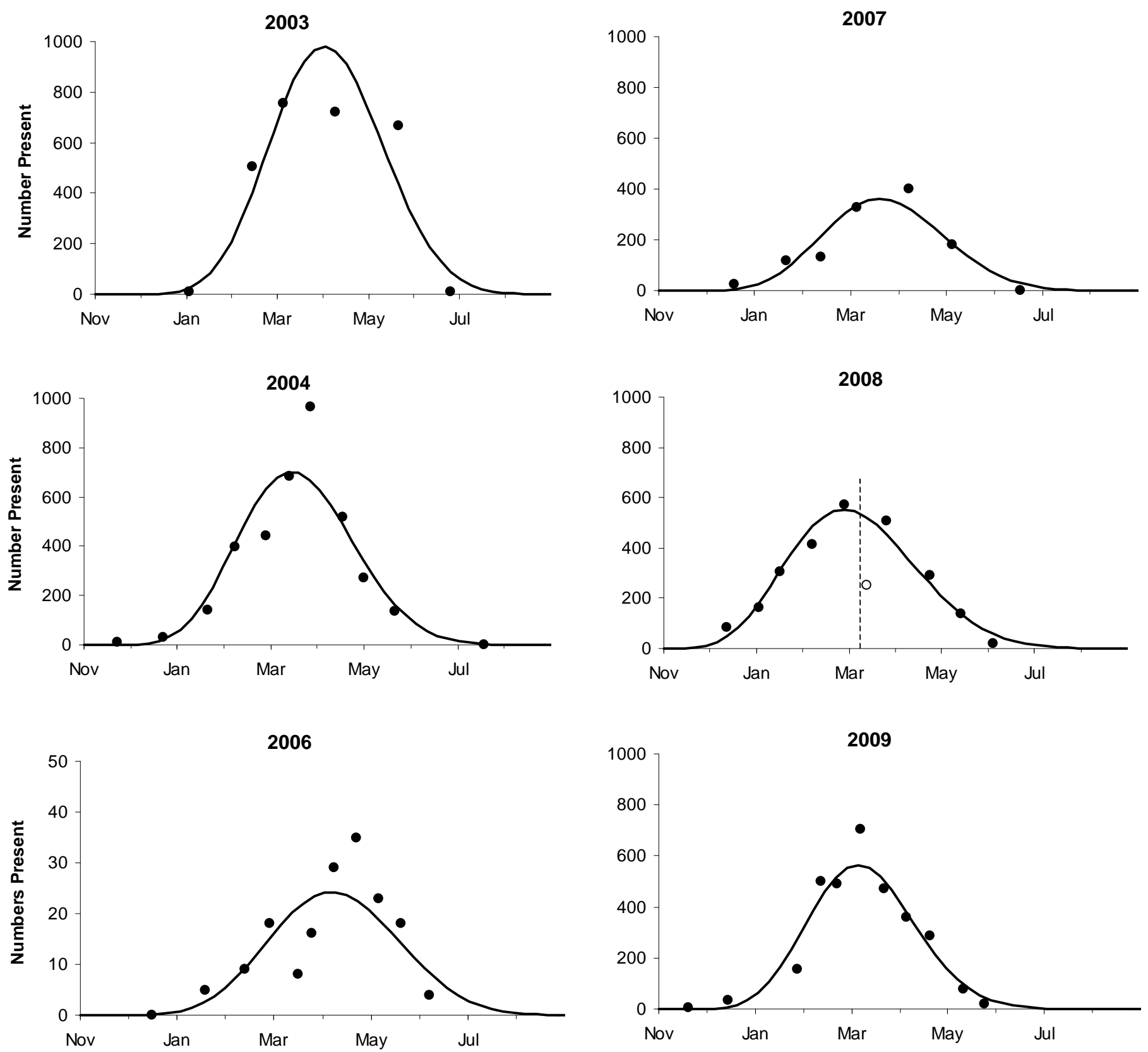

Figure 3. The total number of redds counted on each survey (circles) and the predicted number that are present from the spawning model (black lines) in 2003, 2004, 2006, 2007, 2008, and 2009. The open circle in 2008 represents the count from the first survey after the $2008 \mathrm{HFE}$ (denoted by vertical dashed line), which was not used to estimate parameters of the spawning model. Note the twentyfold reduction in the y-axis scale for 2006. 
Table 2. Statistics used to compute early survival rates for rainbow trout in the Lees Ferry reach, 2003-09. No data were collected in 2005.

[Viable redds are the number of redds that did not experience lethal intestitial gravel temperatures over the period when egg and alevin stages of rainbow trout were incubating and, therefore, have the potential to produce age- 0 trout. Early survival is the ratio of age- 0 abundance on July 15 to the number of viable eggs. Early survival rate measures survival from egg fertilization to approximately 1 to 2 months from emergence when age-0 trout first become vulnerable to capture by electrofishing. The number of viable eggs is simply the product of the number of viable redds and the assumed number of eggs per redd, which in turn is based on assumptions about the number of redds per spawner, and the average size of female spawners (mature female fork length) that is used to calculate fecundity. See text for more details on the calculations]

\begin{tabular}{|c|c|c|c|c|c|c|c|}
\hline Year & Total redds & $\begin{array}{l}\text { Viable } \\
\text { redds }\end{array}$ & $\begin{array}{l}\text { Average } \\
\text { mature } \\
\text { female fork } \\
\text { length } \\
\text { (mm) }\end{array}$ & $\begin{array}{c}\text { Flow- } \\
\text { dependent } \\
\text { incubation } \\
\text { loss } \\
\text { rate }\end{array}$ & $\begin{array}{c}\text { Viable } \\
\text { eggs } \\
\left(\times 10^{6}\right)\end{array}$ & $\begin{array}{c}\text { July-15 } \\
\text { age-0 } \\
\text { abundance } \\
\left(\times 10^{3}\right)\end{array}$ & $\begin{array}{l}\text { Early } \\
\text { survival } \\
\text { rate }\end{array}$ \\
\hline $2003^{1}$ & 3,264 & 2,494 & 334 & 0.24 & 4.84 & 125 & 0.03 \\
\hline 2004 & 2,310 & 1,186 & 317 & 0.50 & 2.18 & 175 & 0.08 \\
\hline 2005 & - & - & - & - & - & - & - \\
\hline 2006 & 88 & 84 & 313 & 0.05 & 0.15 & 89 & 0.59 \\
\hline 2007 & 1,215 & 1,078 & 334 & 0.11 & 2.09 & 192 & 0.09 \\
\hline 2008 & 2,027 & 1,924 & 358 & 0.05 & 3.99 & 750 & 0.19 \\
\hline 2009 & 1,674 & 1,497 & 354 & 0.11 & 3.07 & 425 & 0.14 \\
\hline
\end{tabular}

${ }^{1}$ Age-0 samples only collected in low-angle habitat in 2003. Total population estimate in July derived by expanding the population estimate in low-angle habitat by the average ratio of abundance in lowangle to high-angle habitat determined in other years when both habitats were sampled (2006 excluded because of low densities, which altered ratio).

The hatch-date distribution predicted by spawn-timing and temperature-dependent incubation time occurred approximately 5 weeks later than the spawn-timing distribution (fig. 3). Flow-dependent incubation losses were 24 percent (2003) and 50 percent (2004) in years when within-day variation in flow during winter months was high (nonnative fish suppression flow years) and ranged from 5 percent to 11 percent (average 8 percent) in years when normal operations were conducted (table 2).

Backcalculated hatch-date distributions and the distributions predicted by the flow-dependent incubation loss model were generally very similar (fig. 4). The biggest discrepancy between distributions occurred in 2008, where early survival rates for fish hatching before and until 1 month after the HFE (about April 15) were much lower than expected, with the opposite occurring for fish hatching after this date.

The early survival rate was much higher in 2008 and 2009 following the 2008 HFE. Because of the effects of nonnative suppression flows in 2003 and 2004 and limited spawning in 2006, there is only one acceptable "control" year available for this simple comparison (table 2). Early survival rates in 2008 and 2009, following the HFE, were 2.2- and 1.6-fold higher than in 2007, respectively (table 2). Early survival rates in 2004 and 2007 were very similar, which was surprising considering that the flowdependent incubation loss rate in 2004 was approximately 50 percent compared to 11 percent in 2007. 
Early survival rate was highest in 2006 , when few redds were deposited. These latter two results suggest that early survival rates are density dependent, which was confirmed by the stock-recruitment analysis.

The abundance of age-0 rainbow trout in the Lees Ferry reach in July (2003-09) was resilient to changes in egg deposition, as determined by either the estimated total number of redds or the number of viable redds (fig. 5). In spite of more than a tenfold reduction in egg deposition in 2006, age-0 abundance declined by less than 50 percent compared to abundances in years before the $2008 \mathrm{HFE}$. The fit of the Beverton-Holt model to data from 2003 to 2007 suggests that early survival rates from fertilization to approximately 2 months from hatch are strongly density dependent. While flowdependent incubation losses in 2003 (769 redds) and 2004 (1,067 redds) were substantial (table 2), the stock-recruitment relationship suggests they were not large enough to affect the net recruitment to the age- 0 population. Age- 0 abundance was much higher in July 2008 and 2009 than expected, given the number of viable redds in those years and the 2003 to 2007 stock-recruitment relationship. 

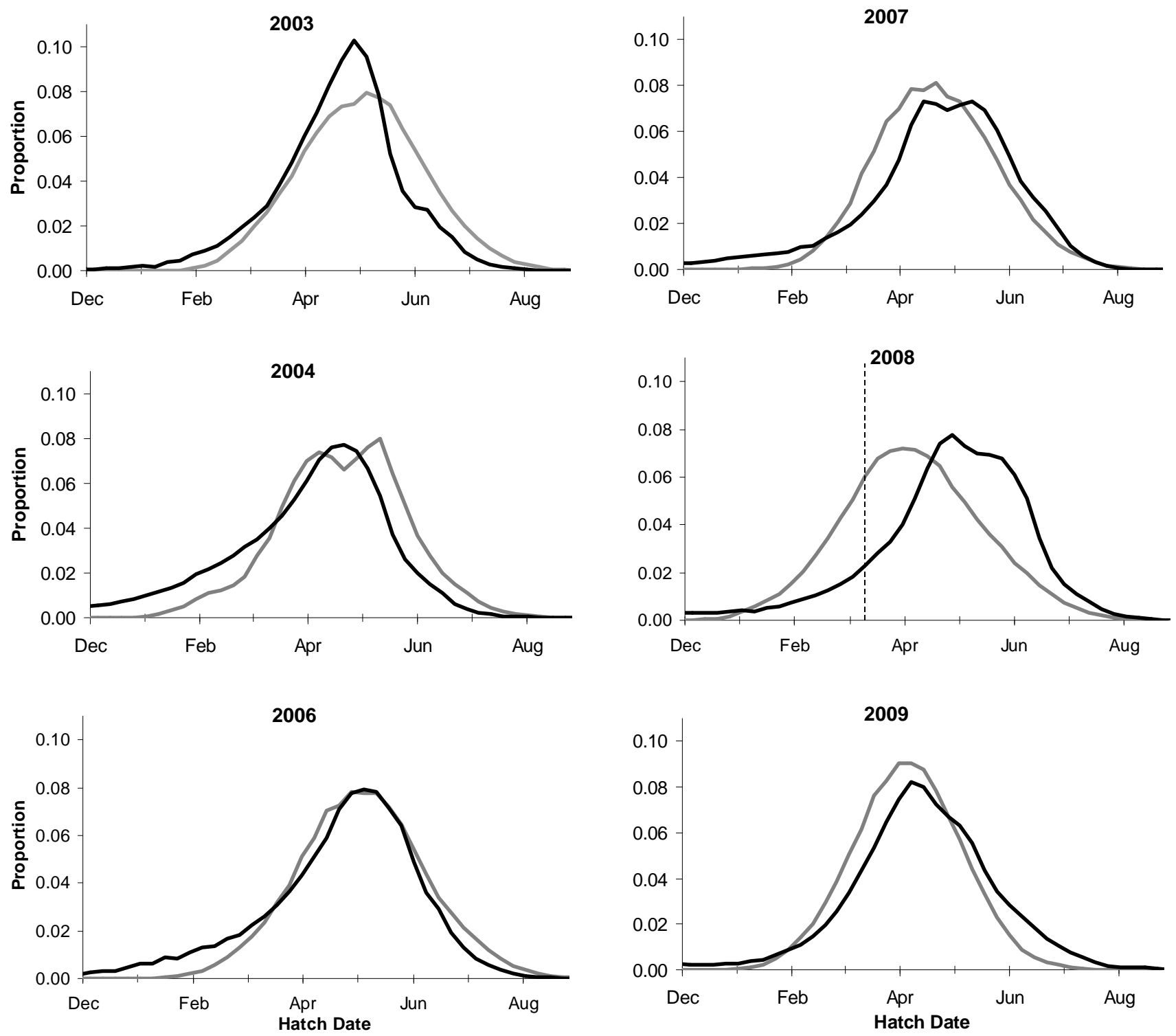

Figure 4. Backcalculated (black lines) and predicted (gray lines) hatch-date distributions in 2003, 2004, 2006, 2007, 2008, and 2009. Predicted distributions were determined using the flow-dependent incubation loss model, which is based on spawn timing, predictions of temperature-dependent incubation time, and temperature-dependent mortality. Survival of weekly cohorts is poorer than expected when the predicted proportion exceeds the backcalculated proportion and better than expected when the opposite occurs. The vertical dashed line in 2008 shows when the March HFE was conducted. 


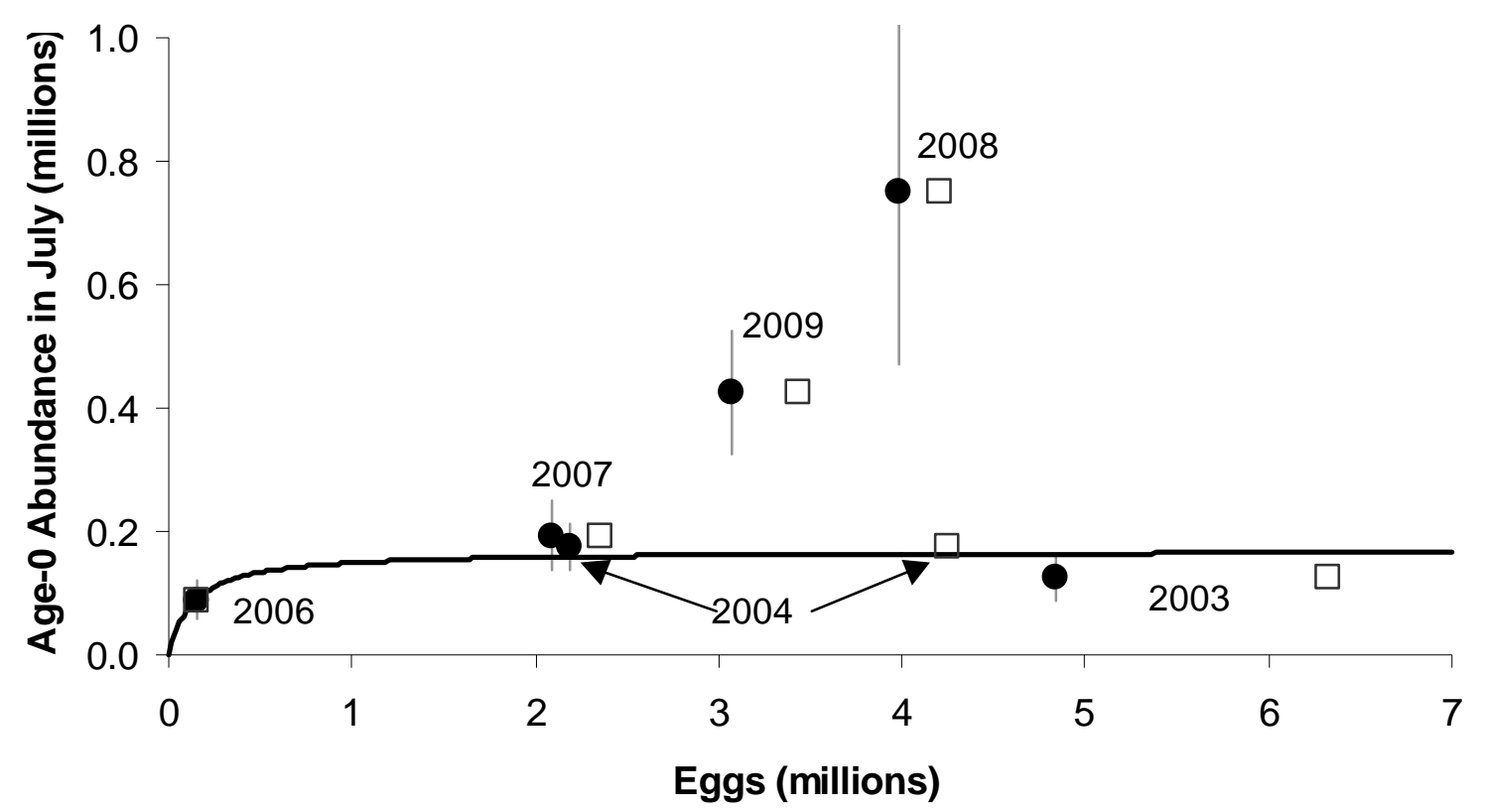

Figure 5. The relations between the total (open squares) and viable (filled circles) number of rainbow trout eggs deposited in the Lees Ferry reach and the resulting population size of age-0 trout on July 15, 2003-09 (no data collected in 2005). The thick black line shows the best-fit Beverton-Holt model to the number of viable eggs using data from 2003-07 only. The light gray vertical lines show the 95-percent confidence limits for the age-0 abundance estimates. See table 2 footnote for details concerning the 2003 age- 0 abundance estimate.

\section{Age-0 Capture Probability}

A total of 2,367 age- 0 trout were released into discrete sites in high-angle habitat on the basis of the combined data from 2007 and 2008, and a total of 664 fish were recaptured. The average capture probability across experiments was 0.29 . Marked age- 0 trout in February and March 2008 typically ranged from 80 to $120 \mathrm{~mm}$ in length and, as expected, were larger than trout marked for the 2007 highangle habitat experiments between July and November (typically 40 to $90 \mathrm{~mm}$ ). Capture probability initially increased with fish size, reached an asymptotic value of approximately 0.3 at $60 \mathrm{~mm}$, remained constant until $140 \mathrm{~mm}$, and then rapidly declined to approximately 0.1 (fig. 6). The single logistic model (equation 1) provided a good fit for fish up to $140 \mathrm{~mm}$, but it overpredicted capture probability for larger fish. When fit to all the data for fish less than $140 \mathrm{~mm}$, this model was indistinguishable from the 2007 relationship in Korman and others (2009). Thus, it is reasonable to assume that the mark-recapture data, when corrected for size effects, are exchangeable among years. The two-stage model, with its additional two parameters (equation 2), provided a better fit to data for fish larger than $140 \mathrm{~mm}$. The AIC score for the single logistic model was 7.4 units larger than the score for the two-stage model, indicating that there was little support for the former (Burnham and Anderson, 2002). However, both models would produce very similar estimates of reachwide abundance based on the expansion of catches at single-pass index sites because only 4 percent of the total catch was greater than $140 \mathrm{~mm}$, the size where predictions between the two models begin to substantively diverge. Therefore, the simpler single logistic model fit to data from marked fish $\leq 140 \mathrm{~mm}$ was used to derive population estimates. 
Aggregated over all experiments in 2008, capture probabilities were 0.29 and 0.22 in February and March, respectively (table 3). Population densities of age-0 trout averaged across six experiments in February (1,500 m sampled) and four experiments in March (1,000 m sampled) were 170 and 179 fish per 100 meters, respectively. Thus, there was no observed negative effect of the March HFE in 2008 on age-0 densities at mark-recapture sites.

The proportion of fish recaptured outside of the section in which they were originally marked was generally low (table 3). Data from two experiments in March 2008 had to be excluded from the analysis because of confusion about release location by mark type (sites 12.3L and 19.5L, see table 3 for an explanation of site naming convention). In February 2008, 89 percent of marks recaptured were in the original 50-m section in which they were released, with 8 percent being recaptured in adjacent sections (either upstream or downstream). It was very rare that fish were recaptured at greater distances ( 2 or more sections away) from the original release sections ( 2 percent). Experiments from March 2008 indicated potential for greater movement, as only 72 percent of fish recaptured were in the original section in which they were marked. The majority of the remaining marked fish moved by only one section (19 percent). As mark-recapture sites used to develop the p-FL relationship in 2008 were $250 \mathrm{~m}$ long (sections 2 to 6), these data indicate very little mark loss over this spatial scale. Thus, the markrecapture data provide reliable estimates of capture probability.

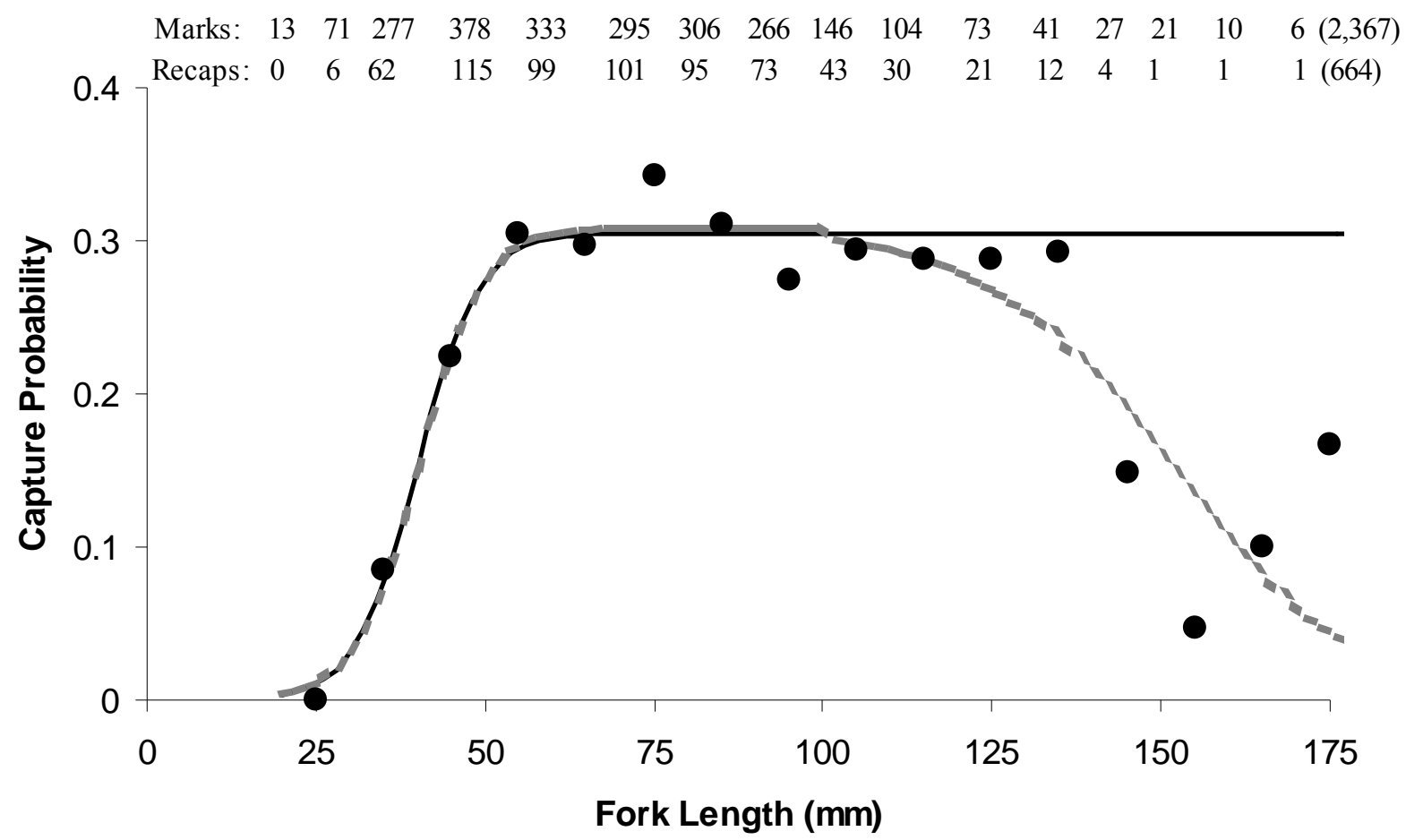

Figure 6. The relationship between fork length and capture probability for age-0 rainbow trout in the Lees Ferry reach based on boat electrofishing in high-angle shorelines, determined from 43 mark-recapture experiments conducted in summer and fall of 2007 and winter of 2008. The data points are the most likely estimates of capture probability (ratio of marks recaptured to marks released) by $10-\mathrm{mm}$ length class. The solid and dashed lines show the best-fit single logistic (equation 1) and two-stage logistic model (equations 1 and 2), respectively. The text at the top of the graph shows the number of marks released and recaptured by size class (totals in parentheses). 


\section{Effects of the HFE on Trends in Age-0 Abundance, Apparent Survival, and Growth}

Abundance of age- 0 trout in the Lees Ferry reach increased in spring as fish emerged from the gravel and recruited to the sampled population (fig. 7). Abundance typically peaked by mid-July and then declined as losses owing to mortality and possibly downstream dispersal or movement to offshore habitat in the Lees Ferry reach that was not sampled outweighed the gains from recruitment. The rate of decline in abundance decreased in fall, and abundance was generally stable through winter. Abundance was lowest in 2006, because of very limited spawning activity, and highest in 2008 and 2009 after the 2008 HFE. The relative decline in abundance over the summer was greatest in years of high abundance, indicating that mortality and possibly emigration are density dependent.

There was a substantial decline in age-0 abundance because of the November 2004 HFE, but this was not the case for the March 2008 HFE. In 2004, there was a 3.2-fold decrease in abundance between November and December trips (fig. 8). There was a 1.9-fold decrease in abundance between November and December trips in 2008. Abundance was twice as high in November 2008 compared to November 2004, and it is likely that there was more density-dependent mortality and dispersal in 2008 . Thus, the effect of the HFE in November 2004 on abundance was likely greater than implied by differences in the November:December ratios among years. Age-0 abundance was very similar across trips that spanned the March 2008 HFE, consistent with results from the mark-recapture experiments (table 3). There was more than a twofold decline in abundance between February and March trips in 2009, which could have been caused by high densities relative to those in 2008 .

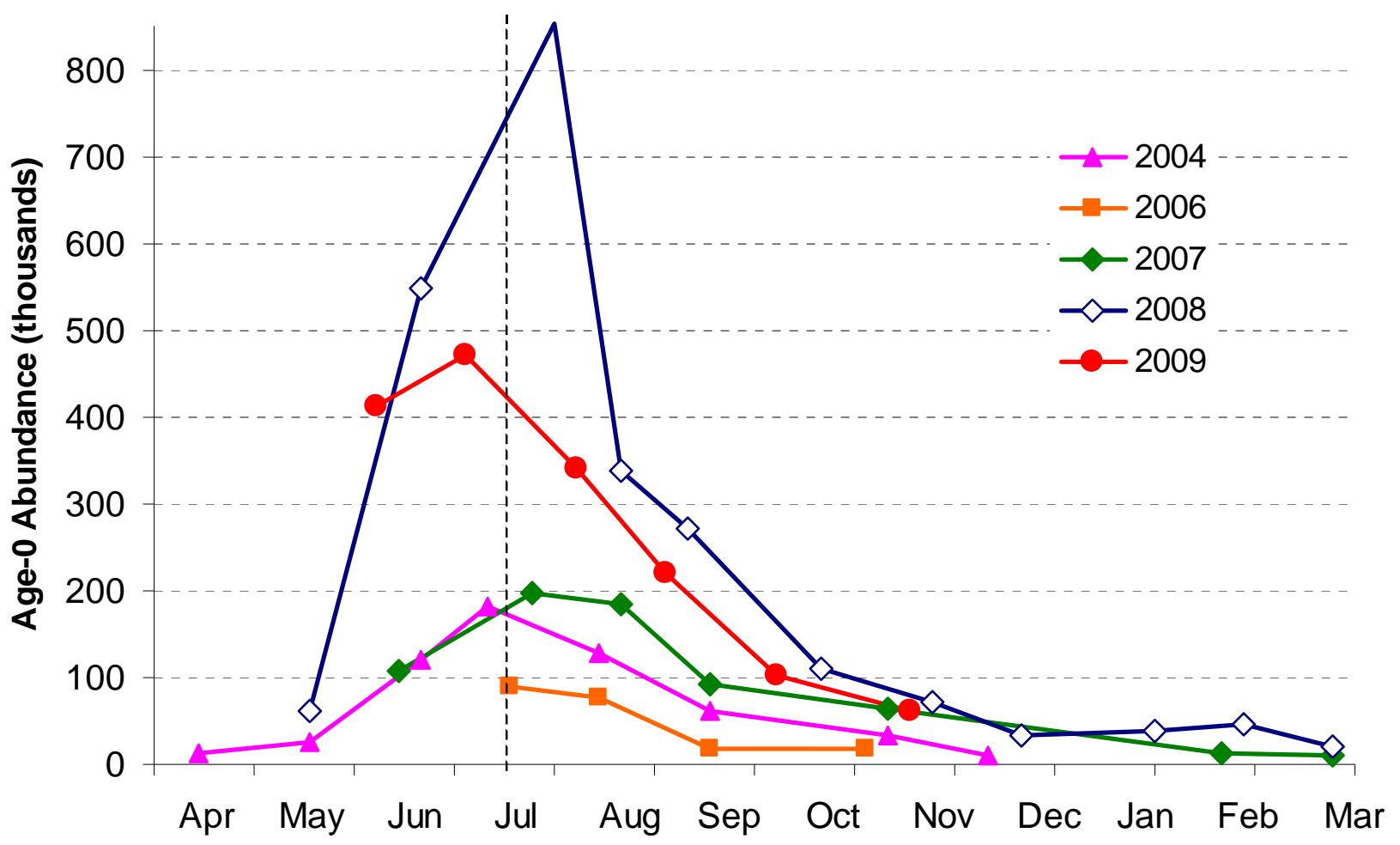

Figure 7. Trends in the abundance of age-0 rainbow trout in the Lees Ferry reach through the year for several different brood years (years in which the eggs that produced the fish were fertilized). The vertical dashed line represents July 15, the date used as a standard time for the annual recruitment values in the stock-recruitment analysis (fig. 5). 


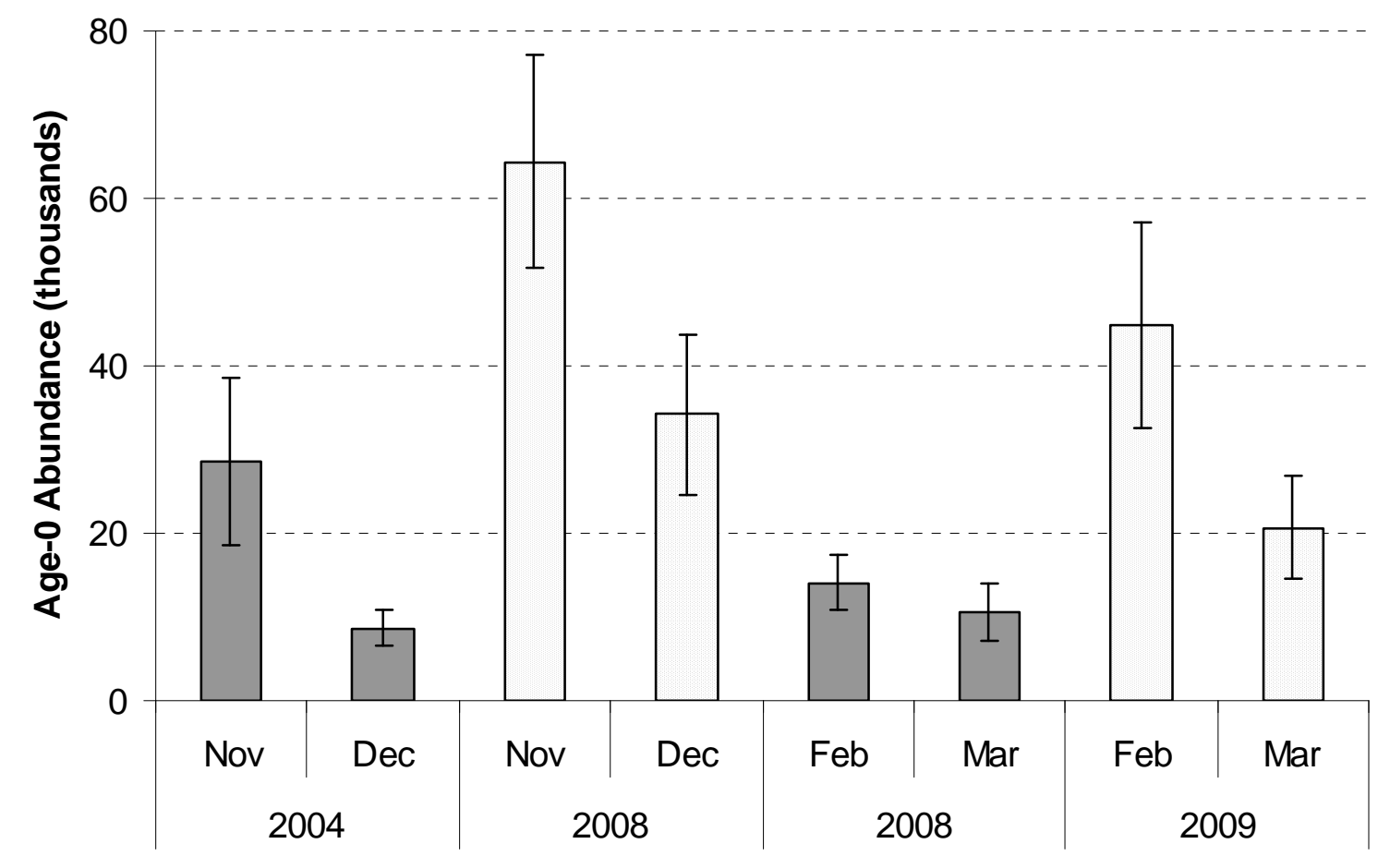

Figure 8. Comparison of abundance of age- 0 rainbow trout in high-angle habitat in the Lees Ferry reach on trips before and after high-flow experiments were conducted (solid bars, Nov-Dec 2004, Feb-Mar 2008) and over similar periods under normal operations (stippled bars, Nov-Dec 2008, Feb-Mar 2009). Error bars denote 95percent confidence limits in abundance estimates. Note that age-0 fish in November and December were from eggs fertilized in the year that is shown on the plot and were on average 7 months old from hatch. Age-0 fish in February and March emerged from eggs fertilized the previous calendar year and were on average 10 months old from hatch. 
Table 3. Statistics from mark-recapture experiments conducted in February and March 2008.

[Site names are given by location along the river in kilometers downstream from Glen Canyon Dam. L and $\mathrm{R}$ refer to the left and right banks, respectively, as viewed in a downstream direction. US/DS denotes upstream or downstream. For each experiment, a 350-m length of continuous bank was divided into 7 adjacent 50-m sections. Fish were initially captured in sections 2 to 6 , given a unique mark, and released back into the section in which they were captured. Twenty-four hours later, fish were recaptured in sections 1 to 7 . Capture probability aggregated over the entire release site, population size, and population density, based on data from sections 2 to 6 only, are shown. The proportion of marks recaptured in each section is also shown. Sites with an $*$ denote experiments where there was confusion over release locations. The aggregate estimates from these experiments are correct, but the movement estimates cannot be determined.]

\begin{tabular}{|c|c|c|c|c|c|c|c|}
\hline \multicolumn{8}{|c|}{ February } \\
\hline & \multicolumn{6}{|c|}{ Site } & \multirow[b]{2}{*}{ Average } \\
\hline & $1.1 \mathrm{~L}$ & $3.4 \mathrm{~L}$ & $5.6 \mathrm{R}$ & $7.5 \mathrm{R}$ & $9.9 \mathrm{~L}$ & $11.5 \mathrm{R}$ & \\
\hline 1st Pass Catch & 35 & 40 & 46 & 63 & 51 & 55 & 48 \\
\hline 2nd Pass Catch & 24 & 45 & 55 & 72 & 59 & 37 & 49 \\
\hline Marks Applied & 30 & 37 & 45 & 57 & 45 & 52 & 44 \\
\hline Recaptures (sections 2-6) & 7 & 16 & 10 & 20 & 13 & 11 & 13 \\
\hline Capture Probability & 0.23 & 0.43 & 0.22 & 0.35 & 0.29 & 0.21 & 0.29 \\
\hline Abundance & 103 & 102 & 248 & 194 & 201 & 175 & 170 \\
\hline Density $(/ 100 \mathrm{~m})$ & 41 & 41 & 99 & 78 & 80 & 70 & 68 \\
\hline \multicolumn{8}{|c|}{ Proportion of all recaptures recovered relative to section they were released in } \\
\hline Within release section & 1.00 & 0.71 & 0.90 & 1.00 & 1.00 & 0.75 & 0.89 \\
\hline $1 \mathrm{US} / \mathrm{DS}$ of release site & & 0.24 & 0.10 & & & 0.17 & 0.08 \\
\hline $2 \mathrm{US} / \mathrm{DS}$ of release site & & & & & & 0.08 & 0.01 \\
\hline $3 \mathrm{US} / \mathrm{DS}$ of release site & & 0.06 & & & & & 0.01 \\
\hline \multicolumn{8}{|c|}{ March } \\
\hline \multicolumn{8}{|c|}{ Site } \\
\hline & $11.5 \mathrm{R}$ & $12.3 \mathrm{~L}^{*}$ & $19.5 \mathrm{~L}^{*}$ & $20.0 \mathrm{R}$ & & & \\
\hline 1st Pass Catch & 64 & 26 & 67 & 51 & & & 52 \\
\hline 2nd Pass Catch & 58 & 21 & 40 & 76 & & & 49 \\
\hline Marks Applied & 62 & 25 & 65 & 50 & & & 51 \\
\hline Recaptures (sections 2-6) & 16 & 5 & 5 & 18 & & & 11 \\
\hline Capture Probability & 0.26 & 0.20 & 0.08 & 0.36 & & & 0.22 \\
\hline Abundance & 225 & 105 & 520 & 211 & & & 179 \\
\hline Density (/100 m) & 90 & 42 & 208 & 84 & & & 60 \\
\hline \multicolumn{8}{|c|}{ Proportion of all recaptures recovered relative to section they were released in } \\
\hline Within release section & 0.44 & & & 1.00 & & & 0.72 \\
\hline $1 \mathrm{US} / \mathrm{DS}$ of release site & 0.38 & & & & & & 0.19 \\
\hline $2 \mathrm{US} / \mathrm{DS}$ of release site & 0.19 & & & & & & 0.09 \\
\hline 3 US/DS of release site & & & & & & & 0.00 \\
\hline
\end{tabular}


Growth rates of age- 0 trout were higher than expected in both 2008 and 2009, after the 2008 HFE was conducted. There were strong linear relations between age from hatch and fork length in all years (fig. 9), with age predicting 82 to 93 percent of the variation in fork length among individuals. Growth rate was highest in $2006(0.46 \mathrm{~mm} /$ day $)$, when age- 0 abundance was lowest. However, growth was nearly as high in $2008(0.43 \mathrm{~mm} /$ day $)$ and $2009(0.44 \mathrm{~mm} /$ day $)$, even though abundance during the summer was eightfold and fivefold higher than abundance in 2006, respectively (fig. 10). This finding indicates that growth rates were higher after the March 2008 HFE than in years before this event after effects of density dependence are accounted for. The HFEs did not have a large effect on the size structure of the age- 0 trout population (fig. 11). The proportion of larger fish increased very slightly after both the November 2004 and March 2008 HFEs, perhaps indicating that smaller fish were more vulnerable to high flows. 

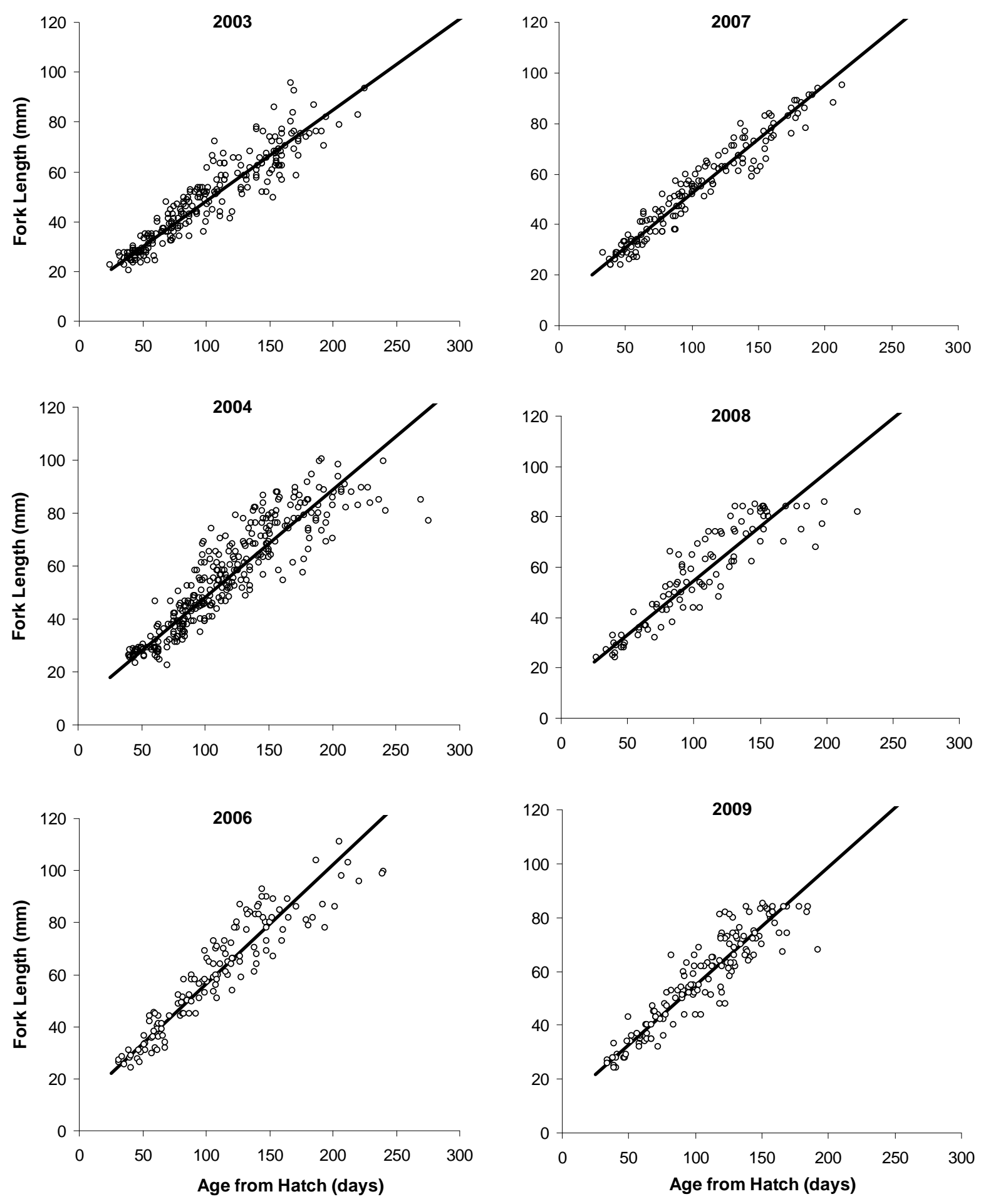

Figure 9. Length-at-age relations for age-0 rainbow trout in the Lees Ferry reach based on counts of daily otolith rings in 2003, 2004, 2006, 2007, 2008, and 2009. No data were collected in 2005. 


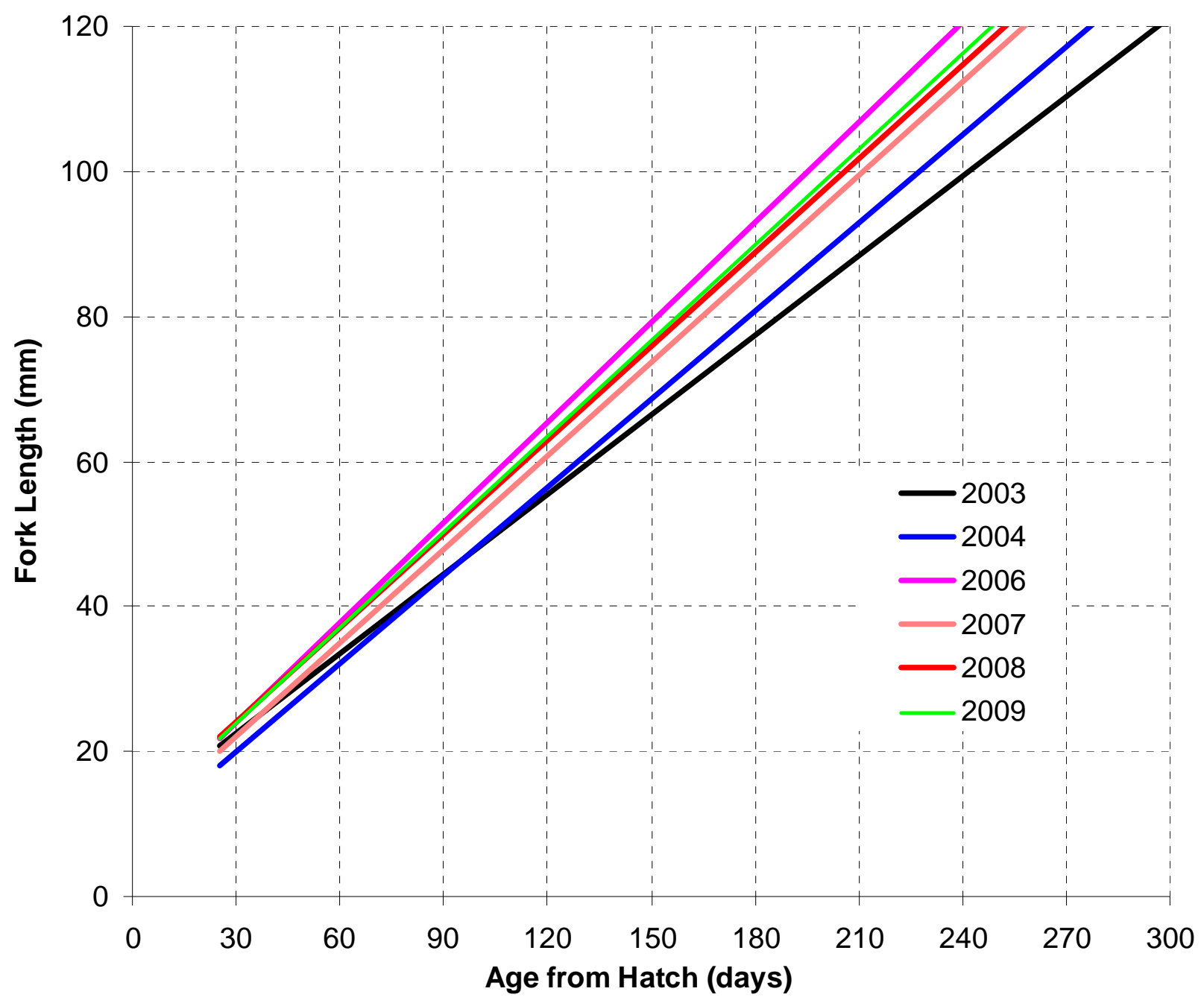

Figure 10. Comparison of annual best-fit length-at-age relations for age-0 rainbow trout in the Lees Ferry reach. No data were collected in 2005. 


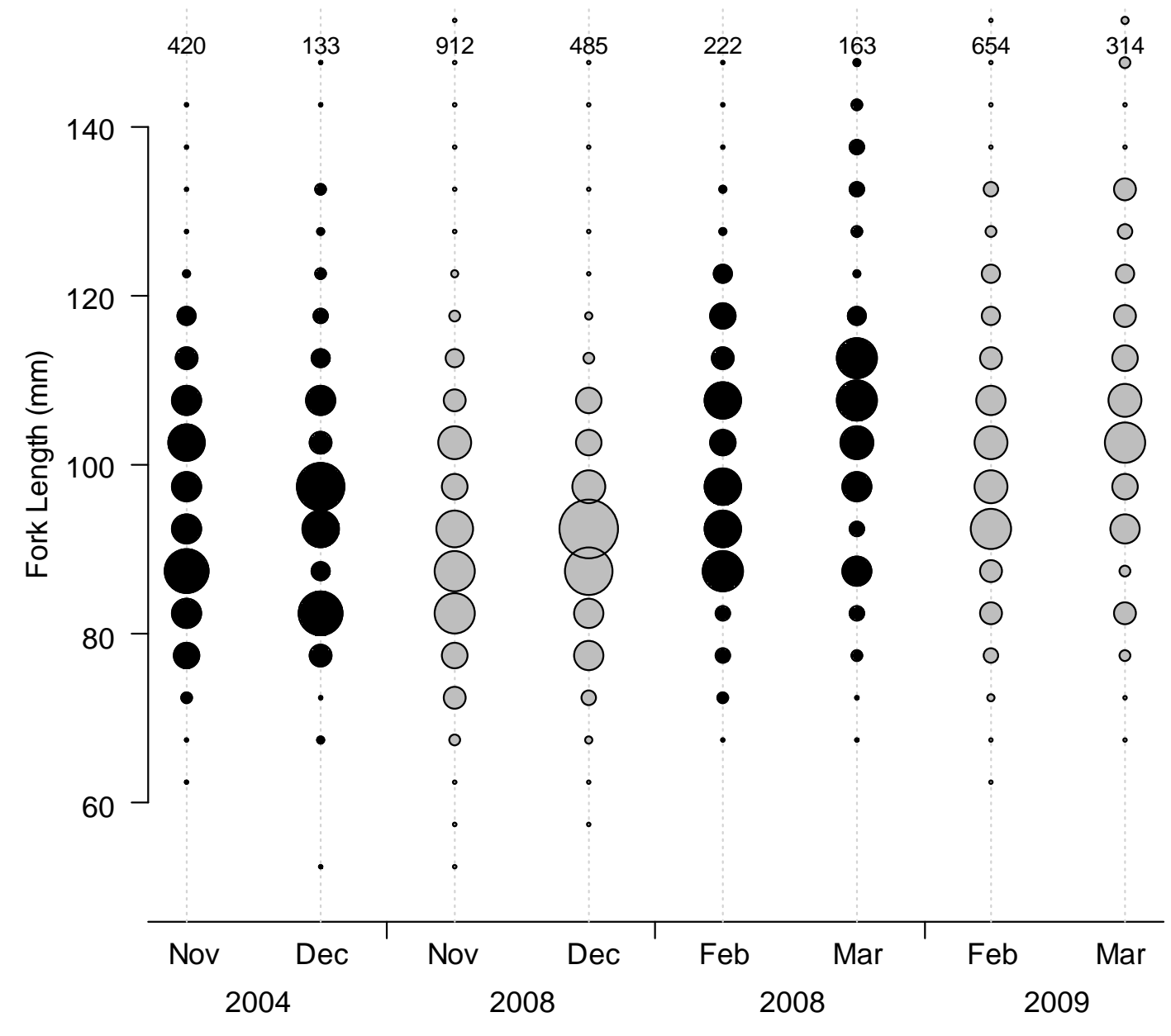

Figure 11. Length frequency distributions for age-0 rainbow trout in the Lees Ferry reach in high-angle habitat on trips before and after HFEs were conducted (black, Nov-Dec 2004, Feb-Mar 2008) and over similar periods under normal operations (gray, Nov-Dec 2008, Feb-Mar 2009). The size of each circle is proportional to the ratio of the catch in each size class relative to the total catch for each trip, corrected for effects of sizedependent differences in capture probability. The distributions therefore represent the expected proportions of individuals in the population. The numbers at the top of the plot show the total catch on each trip. 


\section{Discussion}

Multiple lines of evidence indicated that the March 2008 HFE resulted in a large increase in the early survival rates of rainbow trout in the Lees Ferry reach because of an improvement in habitat conditions. Age- 0 abundance in July 2008 was more than fourfold higher than expected, given the number of viable eggs that produced these fish. The hatch-date analysis indicated that early survival rates were much higher for cohorts that emerged about 2 months after the March HFE. Growth rates of age- 0 trout in the summer of 2008 were virtually the same as in 2006, even though abundance was eightfold greater in 2008. Because growth of juvenile salmonids often declines at higher density (Jenkins and others, 1999; Nislow, 2001; Imre and others, 2005; Ward and others, 2007), this finding likely indicates that the quality of the rearing environment for age-0 trout in the Lees Ferry reach improved after the HFE. We speculate that the 2008 HFE increased interstitial spaces in the substrate and food availability or quality, leading to higher early survival of recently emerged trout and better growth through summer and fall. Interestingly, both age- 0 growth and abundance in 2009 were higher than expected, given age- 0 density and the number of viable eggs deposited in that year, which could indicate that the effect of the 2008 HFE on early life stages is somewhat persistent. Inferences on the effect of Glen Canyon Dam HFEs during late winter to early spring on early survival and growth rates from this analysis are limited by the fact that only one treatment has been conducted and studied using the above methods. When the initial HFE was released in late March 1996, with a peak duration more than twice the 2008 HFE, the rainbow trout monitoring methods used in this study had not yet been applied to the Lees Ferry reach. Owing to this, we recommend that this monitoring effort be repeated if future March HFEs are conducted to determine if the trout responses are similar to those observed in this study.

Long-term studies of juvenile salmonid populations have shown that that the majority of densitydependent mortality occurs during a "critical period" when fry first emerge from their incubation environment and compete for limited feeding territories (Elliot, 1994; Nislow and others, 2004; Einum and Nislow 2005). Very young trout and other salmonids initially conceal themselves within the interstitial spaces of gravel and cobble substrates for much of the day, making only brief forays into the water column to feed, typically at dusk and at night (Chapman and Bjornn, 1969; Contor and Griffith, 1995; Bradford and Higgins, 2001). As juvenile fish grow and their energetic demands and risk to predation change, the extent of concealment declines and fish move into deeper and/or higher velocity habitats (Biro and others, 2003; Rosenfeld and Boss, 2001). These dynamics are consistently observed in fluvial environments and almost certainly apply to age-0 trout in the Colorado River. Habitat quality and availability during the critical period, as affected by operations from Glen Canyon Dam, is likely an important factor controlling juvenile recruitment rates to the adult population of trout in the Lees Ferry reach.

Early survival rates of cohorts that hatched one or more months after the 2008 HFE (about April 15) were much higher than survival rates of cohorts that hatched before this date. This change coincides almost perfectly with the timing of the flood (March 5-9, 2008) and lags in its expected effects. Cohorts that hatched before April 15 that showed relatively poor survival would have been produced from eggs fertilized before March 15. If egg fertilization had taken place no later than early February, some fish would have emerged before the 2008 HFE and would have been vulnerable to displacement and mortality because of increased water velocity (Heggenes and Traaen, 1988; Einum and Nislow, 2005). Most of these fish would have still been in the gravel when the March HFE occurred and would be vulnerable to scour or burial. If they survived, these fish would have emerged within a few months of the 2008 HFE during a period of reduced food availability, given the 1 to 2 month lag between high flows and recovery of the benthic invertebrate community (Shannon and others, 2001). Cohorts 
hatching after April 15 had much higher early survival rates and would have been fertilized after the flood, avoiding scour, burial, or displacement. These cohorts would have emerged after May 15 into a benthic invertebrate community that had recovered from, and was possibly enhanced by, the experimental high-flow release.

The comparison of predicted and backcalculated hatch-date distributions alone cannot be used to compare early survival rates for weekly cohorts in 2008 with those from normal MLFF dam operating years. Such a comparison would help determine which mechanisms were responsible for the unique hatch-date distribution of the 2008 brood. Based on the hatch-date analysis alone, it is unclear whether the early survival rate for the cohorts of fish that hatched before April 15 were anomalously low and survival rates for the cohorts produced after April 15 were normal, or whether the survival of the former cohorts were normal and survival for the latter ones were much higher. Given the much higher early survival rates for the 2008 brood as a whole, relative to other years seen in the stock-recruitment analysis, it is quite certain that the survival rates for cohorts that hatched after April 15 were much higher than normal in 2008. However, it is uncertain whether the survival of early cohorts was similar to previous years or lower. Korman (2009) developed a stock-synthesis model that estimates parameters defining key early life-history processes, including early survival rates for weekly cohorts, by jointly maximizing the fit of the model to redd counts, catch rates, length frequencies, capture probabilities, and length-at-age data. This model will be used to address this uncertainty in a subsequent analysis.

The November 2004 HFE resulted in lower apparent survival of age-0 trout between November and December sample periods compared to the apparent survival over the same interval in 2008 under normal MLFF operations. Density-dependent effects on survival (for example, Elliot, 1994) or downstream dispersal (for example, Close and Anderson, 1992) were likely greater in 2008 than in 2004, because abundance was twofold higher in 2008. As the decline in abundance between November and December in 2004 was 1.7-fold greater than in 2008, in spite of lower densities, the lower apparent survival in 2004 was likely caused by the HFE. However, it is uncertain whether these flow-dependent losses are indicative of increased mortality, greater movement from shoreline habitats to offshore locations in the Lees Ferry reach that were not sampled, or by greater downstream dispersal. It seems unlikely that a HFE spanning only a few days would result in substantial mortality for age- 0 trout in November, because these fish are relatively large. There was no evidence that age- 0 trout make extensive use of offshore habitats on the basis of exploratory offshore sampling in the Lees Ferry reach in fall and winter of 2007 and 2008. Two sampling trips in Marble Canyon found very little evidence for downstream dispersal of age- 0 trout in the summer of 2004 (Korman and others, 2005). However, sampling was not conducted downstream of the Lees Ferry reach immediately before and after the 2004 and 2008 HFEs, so there are no data available to evaluate the downstream dispersal hypothesis. Valdez and others (2001) suggested that the 8-percent decline in catch rates of age-0 trout in the Lees Ferry reach and increased catch rates in reaches in Grand Canyon after the March 1996 HFE were caused by flow-driven downstream displacement. The most logical explanation for the large decrease in abundance of age- 0 trout in the Lees Ferry reach after the November 2004 HFE is that juvenile fish were displaced downstream. A focused monitoring effort in Marble Canyon before and after future HFEs would likely resolve this uncertainty.

The monitoring program for early life stages of rainbow trout in the Lees Ferry reach has provided information that links a variety of dam operations to processes that determine the abundance of the juvenile population (Korman, 2009; Korman and Campana, 2009; this study). The abundance of juveniles ultimately determines recruitment to the adult population in Lees Ferry reach and, perhaps, to the population in Grand Canyon (Coggins, 2008). Because of the relatively high sampling frequency and monitoring of multiple life stages in this study, it was possible to separate the effects of interannual 
variation in egg deposition from effects of flow treatments, as well as to separate the effects of different flow treatments conducted in the same year. For example, the large 2008 cohort in the Lees Ferry reach was not detected in the adult monitoring program until fall 2008 (A. Makinster, Arizona Game and Fish Department, oral commun., 2009). By that point, it was too late to determine whether the larger cohort

was caused by greater spawning activity in spring of 2008, the HFE, or by steady flows implemented on September 1 (fig. 2). Given the historical response of the population to steadier flows during the 1990s (McKinney and others, 2001), it would be quite reasonable to (incorrectly) conclude that the large 2008 cohort was caused by fall steady flows. The approach to experimental management being implemented by the GCDAMP, which is currently largely driven by Endangered Species Act compliance, includes purposeful implementation of multiple treatments within the same year (for example, HFEs and steady flows, mechanical removal and nonnative suppression flows) and limited replication (about 3 years per treatment, at best). Natural variation in upper Colorado River Basin hydrology also increases the complexity of "treatments" (for example, naturally warmer water temperature associated with drought in the upper basin and reduced storage in the reservoir above the dam, coupled with mechanical removal of nonnative fish below the tailwater reach). Given this experimental setting, relatively detailed monitoring of early life stages, such as the program described in this study, is essential to establish the linkage between Glen Canyon Dam operations, other possible nonflow factors, and trends in the abundance of important nonnative and native fish populations living downstream in Grand Canyon National Park.

\section{Acknowledgements}

The U.S. Geological Survey through the Grand Canyon Monitoring and Research Center funded this research. The Bureau of Reclamation provides financial support derived from power revenues to the Grand Canyon Monitoring and Research Center for the science activities it undertakes on behalf of the Glen Canyon Dam Adaptive Management Program. We thank Mike Yard and Lew Coggins for developing the initial ideas for this project and for their effort to obtain funding for this work. Many thanks to Carl Walters, Steve Martell, Mike Bradford, and Eric Parkinson for providing helpful comments and suggestions on modeling approaches, study design, and interpretation of results. Gratitude is also owed to Joe Hazel for conducting and processing the total station surveys and developing stage-discharge relations at the study sites. We are indebted to Mike Yard, Barbara Ralston, Carol Fritzinger, and Matthew Andersen for logistical and administrative support. Thanks to Mike Yard, Dave Foster, Joe Hazel, Steve Jones, Stewart Reeder, Lew Coggins, Jeff Sneep, Steve Hall, Robert Ahrens, Brian Dierker, Peter Weiss, Scott Decker, Gene Tisdale, and Tom Nevin for participating in the field work. Finally, we thank Steven Campana, Drew Dutterer, Bill Pine, Lida Marks, Tania DavignonBurton, and Jenna Denyes for analysis of otolith microstructure.

\section{References Cited}

Allen, G.H., and Sanger, G.A., 1960, Fecundity of rainbow trout from actual counts of eggs: Copeia, v. 3, p. 250-261.

Arndt, S.K.A., Cunjak, R.A., and Benfery, T.J., 2002, Effects of summer floods and spatial-temporal scale on growth and feeding of juvenile Atlantic salmon in two New Brunswick streams: Transactions of the American Fisheries Society, v. 131, no. 4, p. 607-622.

Benenati, E.P., Shannon, J.P., Blinn, D.W., Wilson, K.P., and Hueftle, S.J., 2000, Reservoir-river linkages; Lake Powell and the Colorado River, Arizona: Journal of the North American Benthological Society, v. 19, no. 4, p. 742-755. 
Biro, P.A., Post, J.R., and Parkinson, E.A., 2003, Population consequences of a predator-induced habitat shift by trout in whole-lake experiments: Ecology, v. 84, no. 3, p. 691-700.

Bradford, J.J., and Higgins, P.S., 2001, Habitat-, season-, and size-specific variation in diel activity patterns of juvenile chinook salmon (Oncorhynchus tshawytscha) and steelhead trout (Oncorhynchus mykiss): Canadian Journal of Fisheries and Aquatic Sciences, v. 58, no. 2, p. 365-374.

Burnham, K.P., and Anderson, D.R., 2002, Model selection and multimodel inference (2d ed.): New York, N.Y., Springer-Verlag, 488 p.

Campana, S.E., and Jones, C.M., 1992, Analysis of otolith microstructure data, in Stevenson, D.K., and Campana, S.E., eds., Otolith microstructure examination and analysis: Canada Special Publication of Fisheries and Aquatic Sciences, v. 177, 126 p.

Chapman, D.W., and Bjornn, T.C., 1969, Distribution of salmonids in streams, with special reference to effects of food and feeding, in Northcote, T.G., ed., Symposium on salmon and trout in streams: H.R. Macmillan Lectures in Fisheries, Institute of Fisheries, University of British Columbia, Vancouver, B.C. p. 153-156.

Close, T.L., and Anderson, C.S., 1992, Dispersal, density-dependent growth, and survival of stock steelhead fry in Lake Superior tributaries: North American Journal of Fisheries Management, v. 12, no. 4, p. 728-735.

Coggins, L.G., Jr., 2008, Active adaptive management for native fish conservation in the Grand Canyon; implementation and evaluation: Gainesville, University of Florida, Ph.D. dissertation, 173 p.

Contor, G.R., and Griffith, J.S., 1995, Nocturnal emergence of juvenile rainbow trout from winter concealment relative to light intensity: Hydrobiologia, v. 299, p. 179-183.

Einum, S.A., and Nislow, K.H., 2005, Local-scale density-dependent survival of mobile organisms in continuous habitats; an experimental test using Atlantic salmon: Oecologia, v. 143, no. 2, p. 203-210.

Elliott, J.M., 1994, Quantitative ecology and the brown trout (1 ed.): Oxford, New York, Oxford University Press, 258 p.

Hartman, G.F., and Scrivener, J.C., 1990, Impacts of forestry practices on a coastal stream ecosystem, Carnation Creek, British Columbia: Canadian Bulletin of Fisheries and Aquatic Sciences, v. 223, p. 148.

Heggenes, J., and Traaen, T., 1988, Downstream migration and critical water velocities in stream channels for fry of four salmonid species: Journal of Fish Biology, v. 32, no. 5, p. 717-727.

Hilborn, R., and Walters, C.J., 1992, Quantitative fisheries stock assessment: New York, Chapman and Hall, 570 p.

Holtby, L.B., and Healey, M.C., 1986, Selection for adult body size in female coho salmon (Oncorhynchus kisutch): Canadian Bulletin of Fisheries and Aquatic Sciences, v. 43, p. 1946-1959.

Imre, I., Grant, J.W.A., and Cunjack, R.A., 2005, Density-dependent growth of young-of-year Atlantic salmon Salmo salar in Catamaran Brook, New Brunswick: Journal of Animal Ecology, v. 74, p. 508516.

Jenkins, T.M., Jr., Diehl, S., Kratz, K.W., and Cooper, S.D., 1999, Effects of population density on individual growth of brown trout in streams: Ecology, v. 80, no. 3, p. 941-956.

Jensen, A.J., and Johnsen, B.O., 1999, The functional relationship between peak spring floods and survival and growth of juvenile Atlantic salmon (Salmo salar) and brown trout (Salmo trutta): Functional Ecology, v. 13, no. 6, p. 778-785.

Kondolf, G.M., Cada, G.F., and Sale, M.J., 1987, Assessing flushing-flow requirements for brown trout spawning gravels in steep streams: Water Resources Bulletin, v. 23, no. 5, p. 927-935.

Korman, J., 2009, Early life history dynamics of rainbow trout in a large regulated river: Vancouver, B.C., University of British Columbia, Ph.D. dissertation, 214 p., http://hdl.handle.net/2429/4127. 
Korman, J., and Campana, S.E., 2009, Effects of hydropeaking on nearshore habitat use and growth of age-0 rainbow trout in a large regulated river: Transactions of the American Fisheries Society, v. 138, no. 1, p. $76-87$.

Korman, J., Kaplinski, M., Hazel, J.E.J., and Melis, T.S., 2005, Effects of the experimental fluctuating flows from Glen Canyon Dam in 2003 and 2004 on the early life history stages of rainbow trout in the Colorado River, final report: Ecometic Research, Inc., Northern Arizona University, and U.S. Geological Survey, submitted to U.S. Geological Survey, Grand Canyon Monitoring and Research Center, cooperative agreement no. 04-WRAG-0006 and modification no. 002, 171 p., http://www.gcmrc.gov/library/reports/Biological/Fish_Studies/Korman2005.pdf.

Korman, J., Yard, M., Walters, C., and Coggins, L.G., 2009, Effects of fish size, habitat, flow, and density on capture probabilities of age- 0 rainbow trout estimated from electrofishing at discrete sites in a large river: Transactions of the American Fisheries Society, v. 138, p. 58-75.

Lobon-Cervia, J., 2007, Numerical changes in stream-resident brown trout (Salmo trutta); uncovering the roles of density-dependent and density-independent factors across space and time: Canadian Journal of Fisheries and Aquatic Sciences, v. 64, no. 10, p. 1429-1447.

Lovich, J.E., and Melis, T.S., 2007, The state of the Colorado River ecosystem in Grand Canyon; lessons from 10 years of adaptive ecosystem management: International Journal of River Basin Management, v. 5, no. 3, p. 207-221.

Magee, J.P., McMahon, T.E., and Thurow, R.F., 1996, Spatial variation in spawning habitat of cutthroat trout in a sediment-rich stream basin: Transactions of the American Fisheries Society, v. 125, no. 5, p. $768-779$.

McKinney, T., Speas, D.W., Rogers, R.S., and Persons, W.R., 2001, Rainbow trout in a regulated river below Glen Canyon Dam, Arizona, following increased minimum flows and reduced discharge variability: North American Journal of Fisheries Management, v. 21, no. 1, p. 216-222.

Mietz, S.W., 2003, Evaluating historical electrofishing distribution in the Colorado River, Arizona, based on shoreline substrate: Flagstaff, Northern Arizona University, M.S. thesis, 74 p.

Mitro, M.G., and Zale, A.V., 2000, Predicting fish abundance using single-pass removal sampling: Canadian Journal of Fisheries and Aquatic Sciences, v. 57, no. 5, p. 951-961.

Mitro, M.G., Zale, A.V., and Rich, B.A., 2003, The relation between age-0 rainbow trout (Oncorhynchus mykiss) abundance and winter discharge in a regulated river: Canadian Journal of Fisheries and Aquatic Sciences, v. 60, no. 2, p. 135-139.

Montgomery, D.R., Beamer, E.M., Pess, G.R., and Quinn, T.P., 1999, Channel type and salmonid spawning distribution and abundance: Canadian Journal of Fisheries and Aquatic Sciences, v. 56, no. 3, p. 377-387.

Murle, U., Ortlepp, J., and Zahner, M., 2003, Effects of experimental flooding on riverine morphology, structure and riparian vegetation; the River Spol, Swiss National Park: Aquatic Sciences, v. 65, no. 3, p. 191-198.

Nislow, K.H., 2001, International symposium on the implications of salmonid growth variation: Reviews in Fish Biology and Fisheries, v. 10, no. 4, p. 521-527.

Nislow, K.H., Einum, S.A., and Folt, C.L., 2004, Testing predictions of the critical period for survival concept using experiments with stocked Atlantic salmon: Journal of Fish Biology, v. 65 (supplement A), p. 188-200.

Nislow, K.H., Magilligan, F.J., Folt, C.L., and Kennedy, B.P., 2002, Within-basin variation in short term effects of a major flood on stream fishes and invertebrates: Journal of Fresh Water Ecology, v. 17, no. 2, p. 305-318. 
Rosenfeld, J.S., and Boss, S., 2001, Fitness consequences of habitat use for juvenile cutthroat trout; energetic costs and benefits in pools and riffles: Canadian Journal of Fisheries and Aquatic Sciences, v. 58, no. 2, p. 585-593.

Shannon, J.P., Blinn, D.S., McKinney, T., Benenati, E.P., Wilson, K.P., and O'Brien, C., 2001, Aquatic food base response to the 1996 test flood below Glen Canyon Dam, Colorado River, Arizona: Ecological Applications, v. 11, no. 3, p. 672-685.

Uehlinger, U., Kawecka, B., and Robinson, C.T., 2003, Effects of experimental floods on periphyton and stream metabolism below a high dam in the Swiss Alps (River Spöl): Aquatic Sciences, v. 65, no. 3, p. 199-209.

U.S. Department of the Interior, 1995, Operation of Glen Canyon Dam Final Environmental Impact Statement, Colorado River Storage Project, Coconino County, Arizona: Salt Lake City, Bureau of Reclamation, Upper Colorado Region, 337 p.

U.S. Department of the Interior, 1996, Record of Decision, Operation of Glen Canyon Dam Final Environmental Impact Statement: Washington, D.C., Office of the Secretary of Interior, 15 p.,

Valdez, R.A., Hoffnagle, T.L., McIvor, C.C., McKinney, T., and Leibfried, W.C., 2001, Effects of a test flood on the fishes of the Colorado River in Grand Canyon, Arizona: Ecological Applications, v. 11, no. 3, p. 686-700.

Ward, D.M., Nislow, K.H., Armstrong, J.D., Einum, S., and Folt, C.L., 2007, Is the shape of the density-growth relationship for stream salmonids evidence for exploitative rather than interference competition?: Journal of Animal Ecology, v. 76, no. 1, p. 135-138.

Wright, S.A., Melis, T.S., and Topping, D.J., 2005, Influence of the Glen Canyon Dam operations on downstream sand resources of the Colorado River, in The state of the Colorado River ecosystems in Grand Canyon; a report of the Grand Canyon Monitoring and Research Center 1991-2004: U.S. Geological Survey Circular 1282, p. 17-31.

Wright, S.A., Schmidt, J.C., Melis, T.S., Topping, D.J., and Rubin, D.M., 2008, Is there enough sand? Evaluating the fate of Grand Canyon sandbars: Geological Society of America Today, v. 18, no. 8, p. 4-10. 
